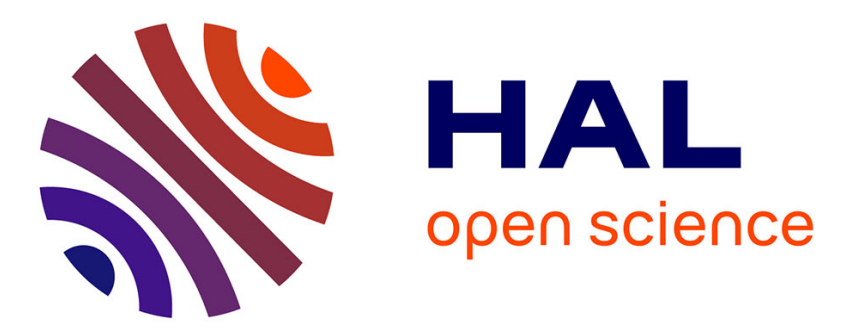

\title{
Clathrate hydrate equilibrium data for gas mixture of carbon dioxide and nitrogen in the presence of an emulsion of cyclopentane in water.
}

Aurélie Galfré, Matthias Kwaterski, Pedro Brantuas, Ana Cameirão, Jean-Michel Herri

\section{To cite this version:}

Aurélie Galfré, Matthias Kwaterski, Pedro Brantuas, Ana Cameirão, Jean-Michel Herri. Clathrate hydrate equilibrium data for gas mixture of carbon dioxide and nitrogen in the presence of an emulsion of cyclopentane in water.. Journal of Chemical and Engineering Data, 2014, 59 (3), pp.592-602. 10.1021/je4002587 . hal-01009692

\section{HAL Id: hal-01009692 \\ https://hal.science/hal-01009692}

Submitted on 3 Jul 2014

HAL is a multi-disciplinary open access archive for the deposit and dissemination of scientific research documents, whether they are published or not. The documents may come from teaching and research institutions in France or abroad, or from public or private research centers.
L'archive ouverte pluridisciplinaire HAL, est destinée au dépôt et à la diffusion de documents scientifiques de niveau recherche, publiés ou non, émanant des établissements d'enseignement et de recherche français ou étrangers, des laboratoires publics ou privés. 


\title{
Clathrate hydrate equilibrium data for the gas
}

\section{mixture of carbon dioxide and nitrogen in the}

\section{presence of an emulsion of cyclopentane in water}

Aurélie Galfré, Matthias Kwaterski, Pedro Brântuas, Ana Cameirão, Jean-Michel Herri*

Ecole Nationale Supérieure des Mines de St Etienne, SPIN Center, PROPICE Department, CNRS-UMR 5307 LGF, 158 cours Fauriel, 42023 St Etienne, FRANCE.

\begin{abstract}
Carbon dioxide and nitrogen gas separation is achieved through clathrate hydrate formation in the presence of cyclopentane. A phase diagram is presented in which the mole fraction of $\mathrm{CO}_{2}$ in the gas phase is plotted against the mole fraction of $\mathrm{CO}_{2}$ in the carbon dioxide + nitrogen + cyclopentane mixed hydrate phase, both defined with respect to total amount of $\mathrm{CO}_{2}$ and $\mathrm{N}_{2}$ in the respective phase. The curve is plotted for temperatures ranging from $283.5 \mathrm{~K}$ to $287.5 \mathrm{~K}$ and pressures from $0.76 \mathrm{MPa}$ to $2.23 \mathrm{MPa}$. The results show that the carbon dioxide selectivity is moderately enhanced when cyclopentane is present in the mixed hydrate phase. Carbon dioxide could be enriched in the hydrate phase by attaining a mole fraction of up to 0.937 when the corresponding mole fraction in the gas mixture amounts to 0.507 . When compared to the three phase hydrate-aqueous liquid-vapour equilibrium in the ternary system
\end{abstract}


$\{$ water + carbon dioxide + nitrogen $\}$, the equilibrium pressure of the mixed hydrate is reduced by 0.95 up to 0.97 . The gas storage capacity approaches $40 \mathrm{~m}^{3}$ gas. $\mathrm{m}^{-3}$ of hydrate. This value turns out to be roughly constant and independent of the gas composition and the operating conditions.

\section{KEYWORDS}

Clathrate hydrate, Carbon dioxide, nitrogen, cyclopentane, separation selectivity

\section{Introduction}

Greenhouse gas emissions have been identified as the major source of global warming. Among the greenhouse gases emitted into the atmosphere due to anthropogenic activities, carbon dioxide $\left(\mathrm{CO}_{2}\right)$ plays a major role. One possible way to reduce the global $\mathrm{CO}_{2}$ emissions is to establish suitable capture processes that can be integrated in existing plants and equipment and by which carbon dioxide can be removed from the considered flue gas streams. Flue gas mixtures of conventional post-combustion power plants are characterised by low carbon dioxide mole fractions ranging from 0.05 to 0.15 . In addition, the respective gas streams are typically emitted at high flow rate. The challenge is to develop $\mathrm{CO}_{2}$ capture technologies by which both energetic and capital costs (size of the units) are minimized. An innovative technology for gas separation and capture could be based on a process making use of gas hydrate formation.

Gas hydrates are non-stoichiometric ice-like crystalline solids consisting of a combination of water molecules and suitable guest molecules under conditions of low temperature and high pressure $^{1}$. The water molecules are arranged in a three dimensional network in such a way that they constitute cavities of different size and shape and size. In the centre of these cavities, an appropriately sized guest molecule can be enclosed. Three different crystalline structures referred to as structure I (sI), structure II ( $\mathrm{sII}$ ) and structure $(\mathrm{sH})$ have been identified for ordinary 
clathrate hydrates. The separation principle is based on the difference in affinity between $\mathrm{CO}_{2}$ and the other gas species for the particular hydrate cavity.

For the typical case of a steel making plant, an energetic costing performed by Duc et al. ${ }^{2}$ showed that the process making use of the semi-clathrate hydrate approach can be competitive compared to conventional capture technologies. The separation cost is mainly due to the gas compression stages. Hence, the objective is to lower the operational pressure.

A thermodynamic promoter enables the formation of hydrates at mild conditions of temperature and pressure. Among well-known thermodynamic promoters, such as tetra- $n$ butylammonium bromide, $\left(\mathrm{C}_{4} \mathrm{H}_{9}\right)_{4} \mathrm{NBr}$ (TBAB) ${ }^{2-6}$ or tetrahydrofuran, $\left(\mathrm{CH}_{2}\right)_{4} \mathrm{O}$ (THF), ${ }^{7-13}$ cyclopentane, $\mathrm{C}_{5} \mathrm{H}_{10}(\mathrm{CP})$, is described in the literature as the strongest organic thermodynamic promoter. ${ }^{14}$ When present in mixtures along with water, $\mathrm{CP}$ forms structure sII hydrates in which cyclopentane could occupy the large cavities whereas the small molecules could get trapped in the small cavities. Four-phases $\mathrm{H}-\mathrm{L}_{\mathrm{w}}-\mathrm{L}_{\mathrm{hc}}-\mathrm{V}$ pressure-temperature equilibrium curves for the ternary systems $\left\{\mathrm{H}_{2} \mathrm{O}+\mathrm{CP}+\mathrm{CO}_{2}\right\}^{15-18}$ and $\left\{\mathrm{H}_{2} \mathrm{O}+\mathrm{CP}+\mathrm{N}_{2}\right\}^{19-21}$ were studied by many authors over the years. For the $\mathrm{CO}_{2}+\mathrm{N}_{2}$ gas mixture, $\mathrm{Li}$ et al. ${ }^{22}$ first showed that the enrichment of $\mathrm{CO}_{2}$ in the corresponding mixed $\mathrm{CO}_{2}+\mathrm{N}_{2}+\mathrm{CP}$ hydrate is increased due to the presence of cyclopentane. Their study focuses on the reaction rates and reveals the impact of the quality of the cyclopentane dispersion. However, the authors only tested the system for a single gas composition and, furthermore, they did not evaluate the gas storage capacity.

In this work, two parallel studies have been carried out. Initially, Henry's constants of $\mathrm{CO}_{2}$ in water, in cyclopentane as well as in a CP-in-water emulsion at several total mass fractions of cyclopentane $w_{\mathrm{CP}}^{\mathrm{EM}}$ have been estimated. The experimental data on Henry's constants of $\mathrm{CO}_{2}$ in the respective media have been well established in the temperature range from $278.3 \mathrm{~K}$ to 
284.2 $\mathrm{K}$ and for pressures below 1.2 MPa. Subsequently, the $\mathrm{H}-\mathrm{L}_{\mathrm{w}}-\mathrm{L}_{\mathrm{hc}}-\mathrm{V}$ four phase equilibrium in the quaternary system $\left\{\mathrm{H}_{2} \mathrm{O}+\mathrm{CP}+\mathrm{CO}_{2}+\mathrm{N}_{2}\right\}$ has been investigated experimentally. Equilibrium data on pressure, temperature and the mole fraction of $\mathrm{CO}_{2}$, determined with respect to the binary sub-system $\left\{\mathrm{CO}_{2}+\mathrm{N}_{2}\right\}$ in the considered phase, have been obtained for the mixed $\mathrm{CO}_{2}+\mathrm{N}_{2}+\mathrm{CP}$ hydrate $\left(z_{\mathrm{CO}_{2}}^{\prime}=x_{\mathrm{CO}_{2}}^{\mathrm{H}} /\left(x_{\mathrm{CO}_{2}}^{\mathrm{H}}+x_{\mathrm{N}_{2}}^{\mathrm{H}}\right)\right)$ and the gas phase $\left(y_{\mathrm{CO}_{2}}^{\prime}=y_{\mathrm{CO}_{2}} /\left(y_{\mathrm{CO}_{2}}+y_{\mathrm{N}_{2}}\right)\right)$. The experimental data on $z_{\mathrm{CO}_{2}}^{\prime}$ are plotted against the data on $y_{\mathrm{CO}_{2}}^{\prime}$ and cover a temperature range from $283.5 \mathrm{~K}$ to $287.5 \mathrm{~K}$ and a pressure range from $0.76 \mathrm{MPa}$ to 2.23 MPa. The experimental results for $z_{\mathrm{CO}_{2}}^{\prime}$ and the equilibrium pressure $p_{\mathrm{eq}, \exp }^{\mathrm{H}-\mathrm{L}_{\mathrm{w}}-\mathrm{L}_{\mathrm{HC}}-\mathrm{G}}$ are compared to corresponding results obtained from a simulation using our in house-software "GasHyDyn" on the ternary system $\left\{\mathrm{H}_{2} \mathrm{O}+\mathrm{CO}_{2}+\mathrm{N}_{2}\right\}$ without $\mathrm{CP}^{23}$. Finally, the benefit of using cyclopentane in mixed $\mathrm{CO}_{2}+\mathrm{N}_{2}+\mathrm{CP}$ hydrates for lowering the equilibrium pressure is quantified and the gas storage capacity GSC is calculated.

Experimental Section

\section{Materials}

All experiments were performed with ultrapure water obtained from the "MilliROs3" purification system (Millipore, Merck AG) which was equipped with a "Milli-Q ${ }^{\circledR}$ AdvantageA10" cartridge (conductivity $\sigma=0.055 \mu{\mathrm{S} . \mathrm{cm}^{-1}}^{-}$natural organic matter $\left.\mathrm{NOM}<510^{-9}\right)$.

Lithium nitrate $\left(\mathrm{LiNO}_{3}\right)$ was provided via a standardised stock solution of the salt $\left(\mathrm{LiNO}_{3}\right.$ mass concentration of $\left.1001 \pm 5 \mathrm{mg} \cdot \mathrm{dm}^{-3}\right)$ in an aqueous nitric acid $\left(\mathrm{HNO}_{3}\right)$ solution $\left(\mathrm{HNO}_{3}\right.$ amount of substance concentration of $0.5 \mathrm{~mol} . \mathrm{dm}^{-3}$ ) as supplied by Merck. 
The suppliers of the remaining substances, along with their purities given in terms of mole fraction, are reported in Table 1.

Table 1. Purities and suppliers of the chemicals

\begin{tabular}{|llll|}
\hline Component & Purity & Source \\
\hline $\mathrm{CO}_{2}$ & $\mathrm{CO}_{2}>0.99995$ & Air Liquid \\
& $\mathrm{C}_{\mathrm{n}} \mathrm{H}_{\mathrm{n}}(\mathrm{n}>2)<5 \times 10^{-6}$ & $\mathrm{O}_{2}<10 \times 10^{-6}$ & \\
& $\mathrm{CO}<2 \times 10^{-6}$ & $\mathrm{H}_{2}<1 \times 10^{-6}$ & \\
& $\mathrm{H}_{2} \mathrm{O}<7 \times 10^{-6}$ & $\mathrm{~N}_{2}<25 \times 10^{-6}$ & \\
& $\mathrm{~N}_{2}>0.9999945$ & & Air Liquid \\
$\mathrm{N}_{2}$ & $\mathrm{C}_{\mathrm{n}} \mathrm{H}_{\mathrm{n}}<0.5 \times 10^{-6}$ & & \\
& $\mathrm{H}_{2} \mathrm{O}(5$ bar $)<3 \times 10^{-6}$ & & \\
& $\mathrm{O}_{2}<2 \times 10^{-6}$ & & \\
& $\mathrm{H}_{2}>0.9999945$ & & \\
$\mathrm{He}$ & $\mathrm{C}_{\mathrm{n}} \mathrm{H}_{\mathrm{n}}<0.5 \times 10^{-6}$ & & \\
& $\mathrm{H}_{2} \mathrm{O}(10$ bar $)<3 \times 10^{-6}$ & Liquid \\
& $\mathrm{O}_{2}<2 \times 10^{-6}$ & Sigma Aldrich \\
\hline $\mathrm{C}_{5} \mathrm{H}_{10}$ & 0.95 & \\
Tween $80^{\circledR}$ & $\mathrm{Not}^{\circledR}$ & & \\
\hline
\end{tabular}

\section{Apparatus}

A schematic representation of the apparatus used in this work is depicted in Figure 1. Further details are provided in the article of Herri et al. ${ }^{23}$ With the experimental setup, thermodynamic equilibria in systems with clathrate hydrate phases could be studied. Besides the measurement of temperature $T$ and pressure $p$, the composition of all existing phases (gas, liquid and hydrate) could be determined. The experiments were performed in a stainless steel high pressure batch reactor (autoclave, total volume $V_{0}=2.46 \mathrm{dm}^{3}$ ). The reactor was temperature controlled via a double jacket connected to an external thermostat (HUBER CC3-K6). Two four vertical-blade 
Rushton turbines mixed both the gas and the liquid phase individually. Thus, each of the fluid phases could be considered as a homogeneous region with respect to all intensive state variables. Two polycarbonate windows $(12 \mathrm{~cm} \times 2 \mathrm{~cm})$, each of which was mounted on either side of the reactor enabled the detection of the occurrence of a solid phase via direct visual observation. Two different pressure transmitters were used in the experiments. A PA/21S pressure sensor (Keller AG) with a range between 0 and $2 \mathrm{MPa}$ and a precision of $0.001 \mathrm{MPa}$ was employed when the operative pressure was less than 1.9 MPa. For pressures exceeding 1.9 MPa, a PA/33X transmitter (Keller AG) covering the pressure range between 0 and $10 \mathrm{MPa}$ at a precision of $0.01 \mathrm{MPa}$ was used. The temperature of each of the two fluid phases was measured by using two Pt100 temperature sensors (Prosensor) with a precision of $0.1 \mathrm{~K}$, respectively. The measured data on temperature and pressure were recorded by means of the data acquisition unit which was directly connected to a personal computer. The emulsion to be tested was poured in a Pyrex cell (upper pressure limit of $10 \mathrm{MPa}$ ) which was located in the autoclave. Liquids could be injected into the pressurised reactor by using a PU-1587 HPLC pump provided by JASCO. Liquid sampling (sample volume of $1-2 \mathrm{~cm}^{3}$ ) could be carried out via the appropriate valve. The initial gas mixture was prepared by injecting the two gases consecutively into the reactor. The composition of the gas phase was determined by on-line gas chromatography (VARIAN gas chromatograph, model $450 \mathrm{GC})$. The gas phase sampling was carried out with a ROLSI instrument. This device collected a small sample of a volume between $1 \mu \mathrm{m}^{3}$ and $5 \mu \mathrm{m}^{3}$ which was directly injected into the loop of the chromatograph. The sample volume could be considered small compared to the total volume of the gas phase in the reactor. 


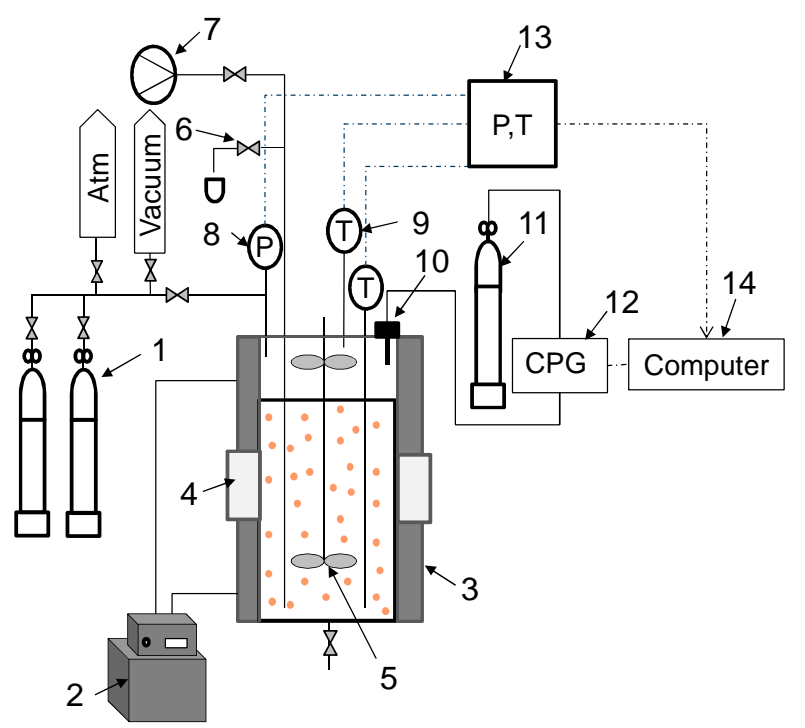

Figure 1. Schematic representation of the experimental setup : (1) gas cylinder $\left(\mathrm{CO}_{2}, \mathrm{~N}_{2}\right)$, (2) cooling system, (3) reactor cell $\left(2.46 \mathrm{dm}^{3}\right)$, (4) viewing window $(12 \mathrm{~cm} \times 2 \mathrm{~cm}),(5)$ stirrer, (6) liquid sampling, (7) HPLC pump, (8) pressure sensor, (9) PT 100 temperature sensor, (10) ROLSI gas sampling, (11) He alimentation, (12) on-line gas chromatography, (13) pressure and temperature view, (14) data acquisition.

Preparation of the cyclopentane in water emulsion

Following the work of $\mathrm{Li}$ et $\mathrm{al}^{22}$, a micro-emulsion of cyclopentane in water, i.e. a fine dispersion of $\mathrm{CP}$ droplets within water, was prepared. After pouring a little amount of the surfactant Tween $80^{\circledR}$ (leading to an overall mass ratio $m_{\text {Tween80 }} / m_{\mathrm{w}}$ of $4.10^{-4}$ in water) into a beaker, the water and a small quantity of lithium nitrate $\left(\mathrm{LiNO}_{3}\right)$ (overall mass fraction $\left.w_{\text {tracer }, 0}=m_{\text {tracer }, 0} /\left(m_{\mathrm{w}, 0}+m_{\text {tracer }, 0}\right) \square 10^{-2}\right)$ were added. The three components were mixed for two minutes by using an Ultra-turax ${ }^{\circledR}$ homogeneizer-disperser (IKA T50, S50N-G45F) at a stirring rate of 125.66 rad.s ${ }^{-1}$. Subsequently, a portion of cyclopentane was added to the mixture. The emulsion was obtained by stirring the mixture for $5 \mathrm{~min}$ by means of the Ultra-turax ${ }^{\circledR}$-disperser at a stirring rate of $544.54 \mathrm{rad} . \mathrm{s}^{-1}$. Throughout this article, the amount of cyclopentane is given in units of mass, whereas its overall composition in the mixture is given in terms of its mass 
fraction with respect to the $\{$ water $+\mathrm{CP}\}$ subsystem defined as $w_{\mathrm{CP}}^{\mathrm{EM}}=m_{\mathrm{CP}} /\left(m_{\mathrm{w}}+m_{\mathrm{CP}}\right)$. The cyclopentane droplets size detected in the emulsion ranged from micrometers to tens of micrometers. A microscopic picture of the emulsion showing the CP-droplets is provided in Figure 2. The droplet size distribution characterising the emulsion quantitatively, is displayed in Figure 3.

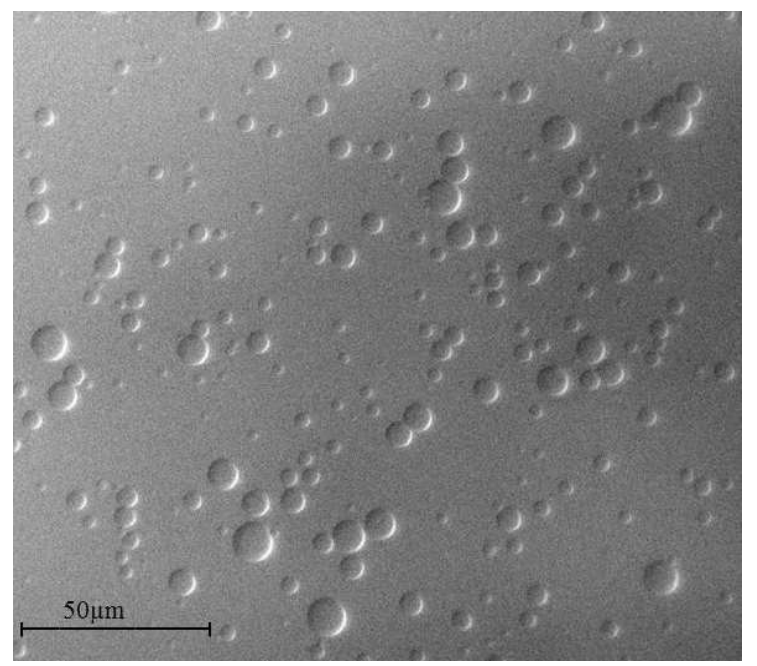

Figure 2. Microscopic picture of the cyclopentane droplets constituting the $\mathrm{CP}$ in water emulsion. Emulsion with an overall CP mass fraction $w_{\mathrm{CP}}^{\mathrm{EM}}$ of 0.0767 .

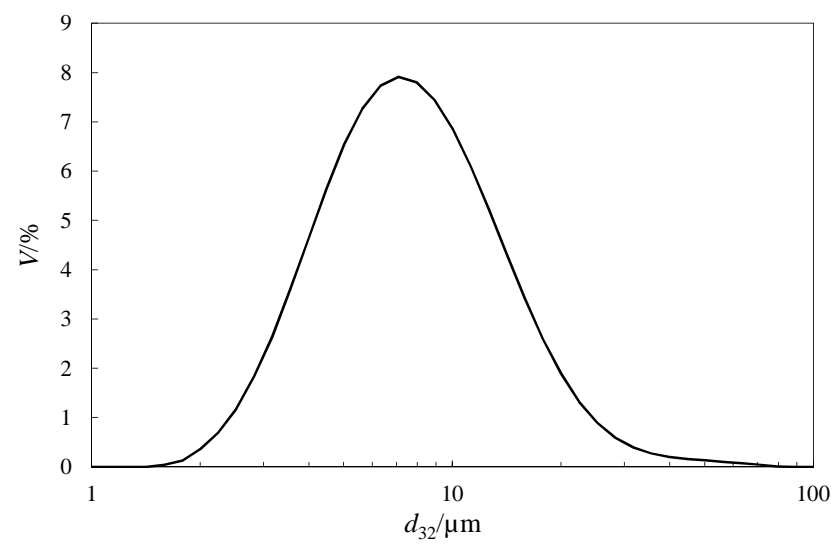

Figure 3. CP droplets size distribution (Malvern Mastersizer hydro 2000G) in a CP in water emulsion with an overall CP mass fraction $w_{\mathrm{CP}}^{\mathrm{EM}}$ of $0.0767 . \mathrm{d}_{32}$ is the Sauter diameter. 
Chromatographic analysis of the aqueous phase

After sampling the emulsion, the liquid sample was centrifuged to remove the organic phase to a great extend and thus to recover the aqueous phase only. The aqueous phase was analysed by means of a DIONEX ionic exchange chromatograph (off-line) to determine the concentration of $\mathrm{LiNO}_{3}$. Throughout this study, $\mathrm{LiNO}_{3}$ was used as an electrolytic tracer. The ionic constituents of $\mathrm{LiNO}_{3}$ were not incorporated into the hydrate structure and hence were concentrated in the aqueous phase during hydrate formation. Via this change in tracer concentration, the water consumption could be estimated. ${ }^{23,24}$

Estimation of the solubility of carbon dioxide in the emulsion

The experimental approach consists in determining the amount of carbon dioxide consumed by the given cyclopentane + water emulsion. Several emulsions of $\mathrm{CP}$ in water with overall mass fractions of cyclopentane $w_{\mathrm{CP}}^{\mathrm{EM}}$ ranging from 0 to 1 were tested.

The reactor containing the empty Pyrex cell was closed, evacuated and flushed with $\mathrm{CO}_{2}$ (three to four times) to erase any trace of other gases. Afterwards, the cell was pressurised with $\mathrm{CO}_{2}$ to the desired operational pressure. The gas phase was sampled by means of the ROLSI instrument and analysed on-line by gas chromatography to check the $\mathrm{CO}_{2}$ purity. The gas was stirred, cooled down and maintained at the temperature of the first dissolution stage set at $284.2 \mathrm{~K}$. After equilibrium had been attained, the stirrer was stopped and the emulsion was injected into the reactor cell via the HPLC pump. The stirrer was turned on at a rate of $41.89 \mathrm{rad} . \mathrm{s}^{-1}$. The observed pressure drop (Figure 4) indicated the dissolution of the gaseous component in the cyclopentanein-water emulsion. After a while, the pressure and temperature attained constant values. This point at which the macroscopic gas dissolution has ceased is regarded as the first equilibrium 
stage (Figure 4). Subsequently, the temperature was decreased by $1 \mathrm{~K}$ and a new equilibrium state, again indicated by stable values of temperature and pressure, was attained after several hours. This procedure was successively repeated until the temperature achieved $278.3 \mathrm{~K}$.

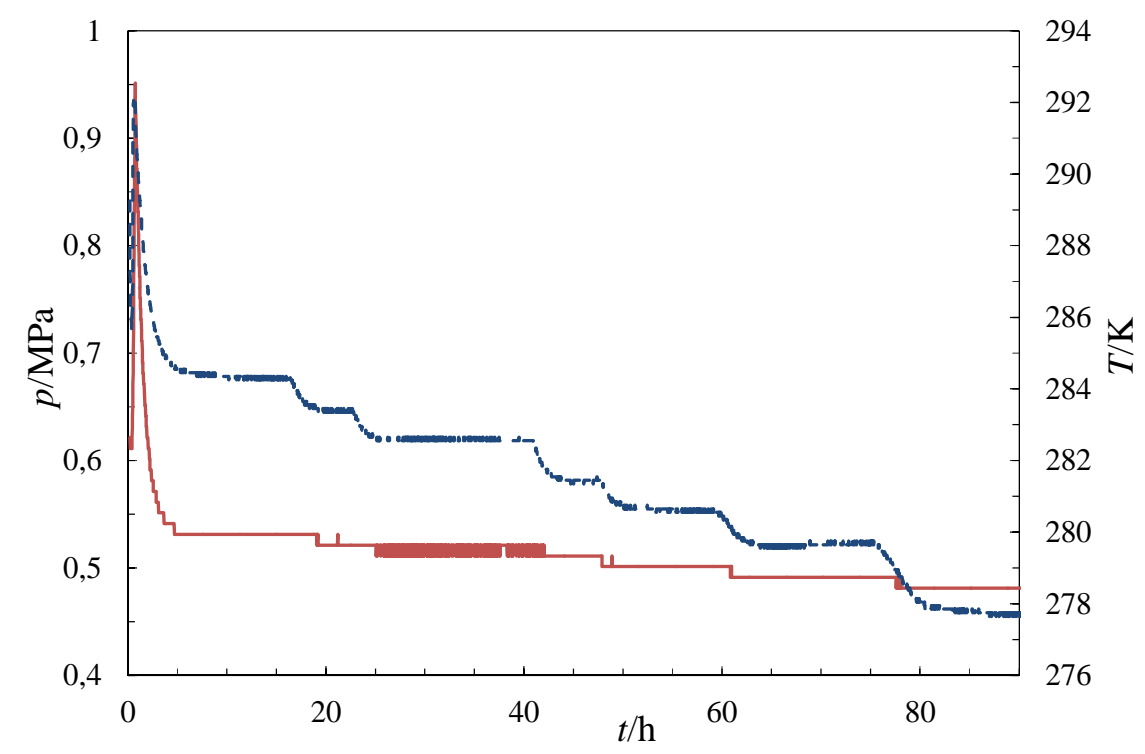

Figure 4. Evolution of (--) pressure $p$ and (---) temperature $T$ of the liquid phase over time $t$. Dissolution of carbon dioxide in an emulsion of cyclopentane in water with an overall cyclopentane mass fraction of $w_{\mathrm{CP}}^{\mathrm{EM}}=0.278$.

Hydrate crystallisation procedure

The experimental procedure is based on an isochoric approach by which the cell temperature is decreased to form the hydrate phase. ${ }^{23,25}$ Mixed $\mathrm{CO}_{2}+\mathrm{N}_{2}+\mathrm{CP}$ hydrates were obtained by establishing hydrate forming state conditions in the reactor which was initially filled with a $\mathrm{CO}_{2}+\mathrm{N}_{2}$ gas mixture to which the emulsion had subsequently been added. The emulsion was comprised of $w_{\mathrm{CP}}^{\mathrm{EM}}=0.0670$ of $\mathrm{CP}$ in water, containing an overall mass fraction of $\mathrm{LiNO}_{3}$ of $1.10^{-2}$ and an overall mass ratio of the emulsifier Tween $80^{\circledR}$ to water, $m_{\text {Twenn80 }} / m_{\mathrm{w}}$, of $4.10^{-4}$. 
Initially, the reactor containing the empty Pyrex cell was closed and evacuated. The reactor was flushed three to four times with the first gas $\left(\mathrm{CO}_{2}\right.$ or $\left.\mathrm{N}_{2}\right)$ to erase any trace of other gases before it was filled with the considered gas to the desired pressure. The gas phase was sampled with the ROLSI instrument and analysed on-line by gas chromatography in order to check its purity. After stabilisation of temperature (typically $282 \mathrm{~K}$ ) and pressure, the second gas was injected until the desired operational pressure was reached (Figure 5). The gas mixture was stirred and cooled down again to the target temperature (typically $282 \mathrm{~K}$ ). When constant values of temperature and pressure were reached, the gas phase was analysed by gas chromatography to determine the initial gas composition.

In the following step, the stirrer was stopped and (0.8-1) dm3 of the emulsion was injected into the reactor by means of the HPLC pump (Figure 5). Upon introduction of the emulsion, a simultaneous increase of both temperature and pressure was observed. This simultaneous rise in $T$ and $p$ was on the one hand due to the fact that the liquid mixture was prior to injection at ambient temperature, and on the other hand due to the gas compression. The stirrer was started and a pressure drop (Figure 5) was observed which indicated the dissolving of the gas components in both the aqueous phase and the cyclopentane-rich organic phase. After a short time, a sudden increase in temperature accompanied by a pressure drop indicated the appearance of the first crystals (exothermic process). The crystallisation process was accompanied by a pressure decrease due to the gas consumption during the formation of the mixed hydrates (Figure 5). The gas phase, sampled with the ROLSI instrument, was analysed by on-line gas chromatography (Figure 6). After crystallisation had terminated the values of pressure and temperature approached constant values indicating that the system attained equilibrium. At this instant of time, samples of the emulsion and the gas phase were taken and analysed. A typical 
diagram showing the mole fraction of $\mathrm{CO}_{2}$ in the gas phase against time during the dissolving and crystallisation steps is presented in Figure 6.

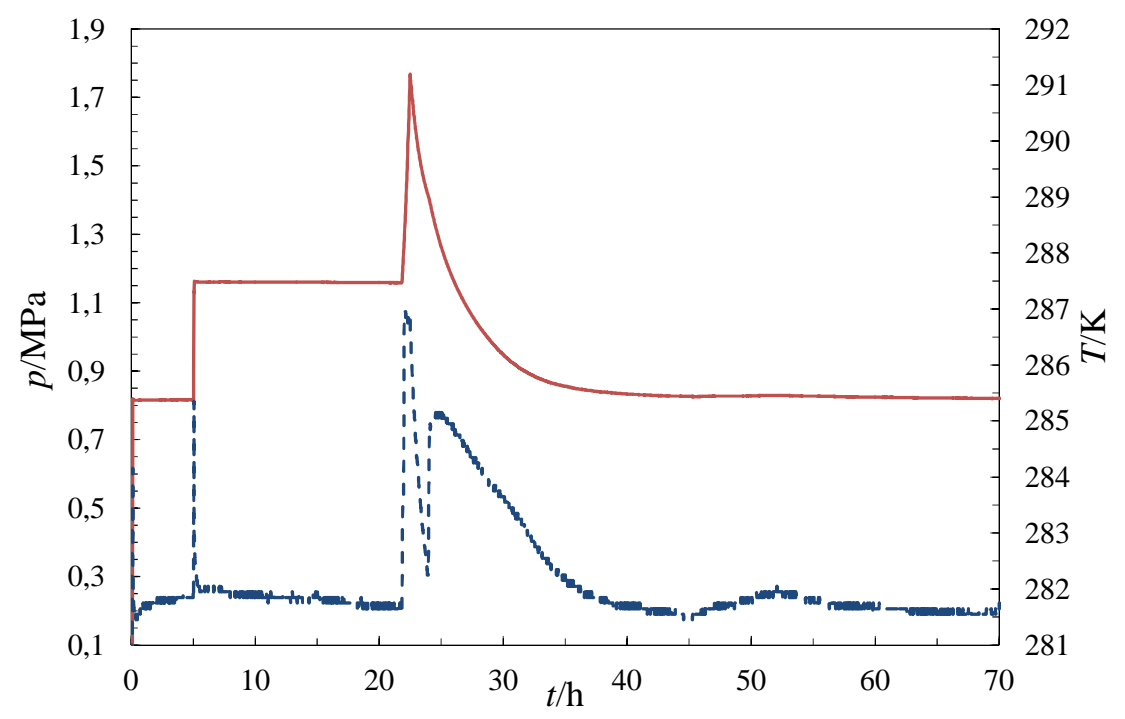

Figure 5. Dissolving and crystallisation steps. Evolution of (----) liquid temperature $T$ and (-) pressure $p$ over time $t$ in the reactor initially filled with a CP in water emulsion with $w_{\mathrm{CP}, 0}^{\mathrm{EM}}=0.0661$ and an initial gas mixture of composition $y_{\mathrm{CO}_{2}, 0}^{\prime} / y_{\mathrm{N}_{2}, 0}^{\prime}=0.718 / 0.282$. 


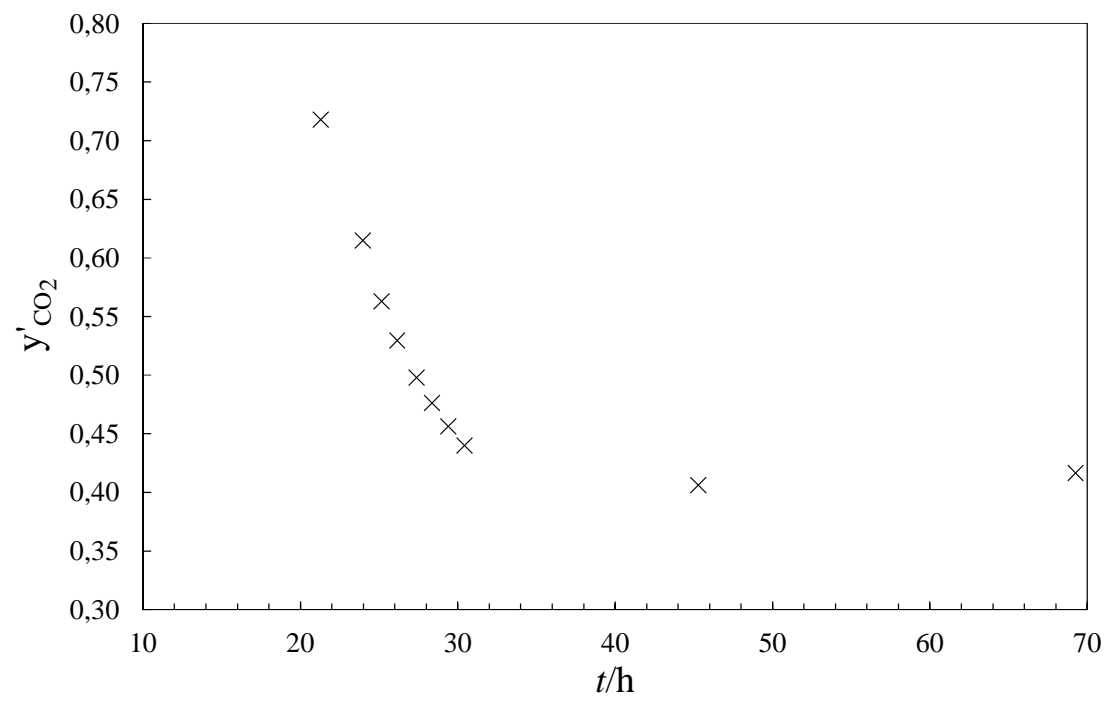

Figure 6. Dissolving and crystallisation steps. Evolution of the gas phase mole fraction of $\mathrm{CO}_{2}$ (relative to the total amount of the two gases) $y_{\mathrm{CO}_{2}}^{\prime}$ over time $t$ for a $\mathrm{CP}$ in water emulsion with $w_{\mathrm{CP}, 0}^{\mathrm{EM}}=0.0661$ and an initial gas mixture of composition $y_{\mathrm{CO}_{2}, 0}^{\prime} / y_{\mathrm{N}_{2}, 0}^{\prime}=0.718 / 0.282$ at $t=21.4$ h. $(\times)$ Experimental data.

Hydrate dissociation procedure

The dissociation of the hydrate phase was performed by means of an isochoric procedure in which the reactor was heated in increments of $\Delta T=1 \mathrm{~K} \cdot{ }^{1,23,25}$ Each of the incremental increases in temperature was accompanied by a simultaneous increase in pressure which was caused by the liberation of gas during the hydrate dissociation (Figure 7). After several hours, constant values for $T$ and $p$ were approached, indicating that thermodynamic equilibrium was attained. The gas and the emulsion were sampled and the composition of each phase (liquids, hydrate, gas) at equilibrium was calculated (the calculation method is presented in detail in the supporting information). In the next step, the temperature was increased by $1 \mathrm{~K}$ and a new equilibrium state, 
characterised by new values of temperature and pressure, was again reached after several hours. This procedure was successively repeated until the hydrate phase was completely dissociated.

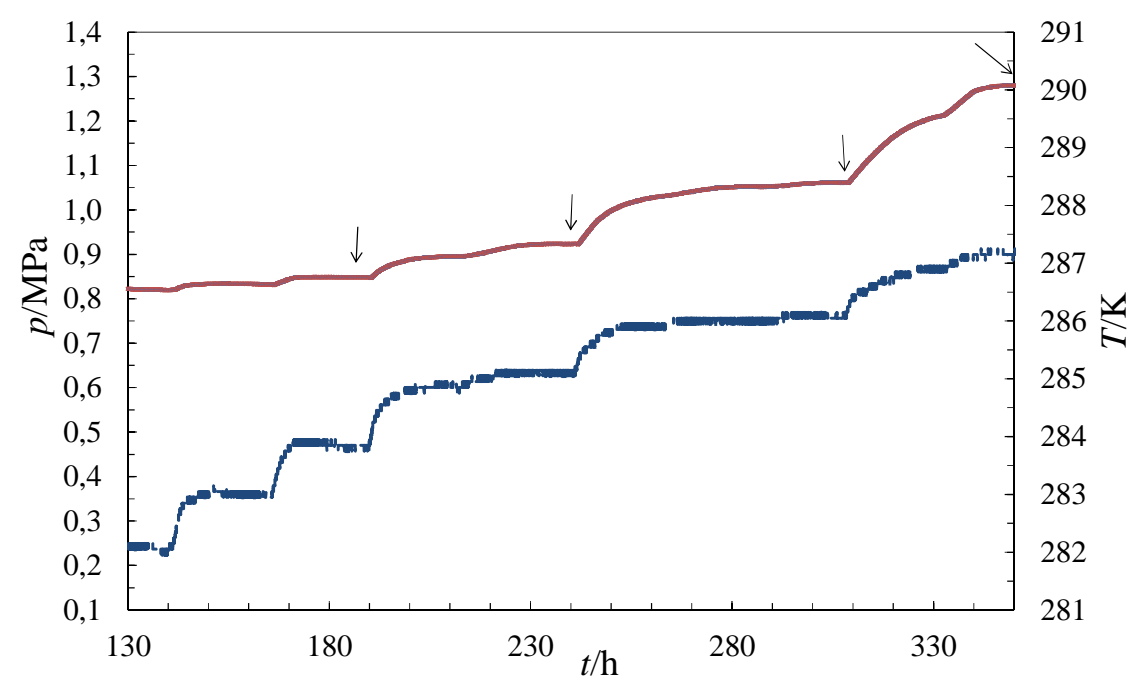

Figure 7. Dissociation step. Evolution of (-) pressure $p$ and (---) liquid temperature $T$ over time $t$. CP in water emulsion with an initial overall mass fraction of cyclopentane $w_{\mathrm{CP}, 0}^{\mathrm{EM}}=0.0661$ and initial gas composition of $y_{\mathrm{CO}_{2}, 0}^{\prime} / y_{\mathrm{N}_{2}, 0}^{\prime}=0.718 / 0.282$. At each point marked with an arrow $\rightarrow$, gas sampling and gas chromatography, liquid sampling, centrifugation of the sample and ion exchange chromatography were performed.

In this work, intermediate heating stages were regarded as true equilibrium states ${ }^{26}$. In practice, it took several hours, before stable values of temperature, pressure and gas composition were obtained and to be certain that equilibrium was attained. ${ }^{25}$

As long as cyclopentane was not completely consumed during the mixed hydrate phase formation, the equilibrium stages, visualised in Figure 7, were independent of the overall cyclopentane composition. 
Experimental results and discussion

Results of the solubility measurements of $\mathrm{CO}_{2}$ in the cyclopentane in water emulsions

From the series of measurements of the solubility of carbon dioxide in the cyclopentane in water emulsions, experimental data on Henry's constants for $\mathrm{CO}_{2}$ in water $k_{\mathrm{H}, \mathrm{CO}_{2}, \mathrm{w}}^{\mathrm{L}_{\mathrm{w}}}(T, p)$ and in cyclopentane $k_{\mathrm{H}, \mathrm{CO}_{2}, \mathrm{CP}}^{\mathrm{L}_{\mathrm{hc}}}(T, p)$ were derived in the temperature range from $278.3 \mathrm{~K}$ to $284.2 \mathrm{~K}$ and at pressures below $1 \mathrm{MPa}$. The emulsions investigated are reported in Table 2. For an overall mass fraction of cyclopentane less than 0.1723 , the system is a cyclopentane in water emulsion. At values for the overall mass fraction of cyclopentane greater than 0.2780 , the system appears as an emulsion of water in cyclopentane.

Table 2. Characteristics of the emulsions in terms of the overall mass fraction of cyclopentane $w_{\mathrm{CP}, 0}^{\mathrm{EM}}$ a , the total mass of emulsion $m_{0}^{\mathrm{EM} a}$ and the number of runs.

\begin{tabular}{|ccc|}
\hline $\begin{array}{c}\text { Initial overall CP mass fraction } \\
w_{\mathrm{CP}, 0}^{\mathrm{EM}}\end{array}$ & $\begin{array}{c}\text { Total mass of emulsion } \\
m_{0}^{\mathrm{EM}} / \mathrm{g}\end{array}$ & Number of runs \\
\hline 0 & 800.00 & 2 \\
0.0176 & 818.01 & 1 \\
0.0183 & 800.04 & 1 \\
0.0360 & 800.06 & 1 \\
0.0767 & 800.52 & 1 \\
0.1723 & 810.76 & 1 \\
0.2780 & 737.17 & 1 \\
0.6354 & 587.62 & 2 \\
1.00 & 605.31 & 1 \\
\hline
\end{tabular}

\footnotetext{
${ }^{a}$ Relative standard uncertainty $u_{\mathrm{r}}\left(m_{0}^{\mathrm{EM}}\right)=0.003$ and combined relative standard uncertainty $u_{\mathrm{c}, \mathrm{r}}\left(w_{\mathrm{CP}, 0}^{\mathrm{EM}}\right)=0.005$.
} 
This procedure allows us firstly to check the reciprocal influence of water and $\mathrm{CP}$ on the gas solubility. By varying the overall mass fraction of $\mathrm{CP} w_{\mathrm{CP}, 0}^{\mathrm{EM}}$, a case study analysis has been performed coupled with a repeatability measurement, the Henry's constant $k_{\mathrm{H}, \mathrm{CO}_{2}, \mathrm{CP}}^{\mathrm{L}_{\mathrm{cc}}}\left(T, p_{\mathrm{CP}}^{\mathrm{o}, \sigma}\right)$ and $k_{\mathrm{H}, \mathrm{CO}_{2}, \mathrm{w}}^{\mathrm{L}_{\mathrm{w}}}\left(T, p_{\mathrm{w}}^{\mathrm{o}, \sigma}\right)$ being measured from a slope determination.

Henry's constant of $\mathrm{CO}_{2}$ in water and in $\mathrm{CP}$, respectively, were calculated based on hypothesis and according to equations described in detail in the supporting information. Briefly, a general relation (eq 1) between the total amount of carbon dioxide dissolved in the emulsion $n_{j}^{\mathrm{EM}}$, Henry's constant of $\mathrm{CO}_{2}$ in cyclopentane $k_{\mathrm{H}, j, \mathrm{CP}}^{\mathrm{L}_{\mathrm{cc}}}\left(T, p_{\mathrm{CP}}^{\mathrm{o}, \sigma}\right)$ and in water $k_{\mathrm{H}, j, \mathrm{w}}^{\mathrm{L}_{\mathrm{w}}}\left(T, p_{\mathrm{w}}^{\mathrm{o}, \sigma}\right)$ and the overall mass fraction of cyclopentane in the emulsion $w_{\mathrm{CP}, 0}^{\mathrm{EM}}$ was obtained from mass balances.

$\frac{n_{j}^{\mathrm{EM}} M_{\mathrm{w}}}{\phi_{j}^{G} p m_{0}^{E M}}=w_{\mathrm{CP}, 0}^{\mathrm{EM}}\left(\frac{M_{\mathrm{w}}}{M_{\mathrm{CP}} k_{\mathrm{H}, j, \mathrm{CP}}^{\mathrm{L}_{\mathrm{hc}}}\left(T, p_{\mathrm{CP}}^{\mathrm{o}, \sigma}\right)}-\frac{1}{k_{\mathrm{H}, j, \mathrm{w}}^{\mathrm{L}_{\mathrm{w}}}\left(T, p_{\mathrm{w}}^{\mathrm{o}, \sigma}\right)}\right)+\frac{1}{k_{\mathrm{H}, j, \mathrm{w}}^{\mathrm{L}_{\mathrm{w}}}\left(T, p_{\mathrm{w}}^{\mathrm{o}, \sigma}\right)} ; j=C O_{2}$

In eq $1, M_{\mathrm{w}}$ and $M_{\mathrm{CP}}$ are the molar mass of water and cyclopentane, $\phi_{j}^{\mathrm{G}}$ is the fugacity coefficient of $\mathrm{CO}_{2}$ in the gas phase, $p$ is the pressure and $m_{0}^{\mathrm{EM}}$ is the total mass of emulsion.

The total amount of carbon dioxide dissolved in the emulsion $n_{j}^{\mathrm{EM}}$ could also be derived from the mass balance in the gas phase.

$$
n_{j}^{\mathrm{EM}}=\frac{1}{R}\left(\frac{p_{0} V_{\mathrm{R}}}{Z\left(T_{0}, p_{0}, n_{j, 0}^{\mathrm{G}}\right) T_{0}}-\frac{p V^{\mathrm{G}}}{Z\left(T, p, n_{j}^{\mathrm{G}}\right) T}\right) ; j=\mathrm{CO}_{2}
$$

In eq $2, R=(8.3144621 \pm 0.0000075) \mathrm{J} \cdot \mathrm{K}^{-1} \cdot \mathrm{mol}^{-1}$ is the universal gas constant. ${ }^{27}$ The subscript 0 is used to designate the initial value of the state variables. Hence, $T_{0}, p_{0}$ and $Z\left(T_{0}, p_{0}, n_{j, 0}^{\mathrm{G}}\right)$ denote the initial values of temperature, pressure and compressibility factor at the instant prior to the introduction of the emulsion. The corresponding quantities without the index " 0 " refer to each of the equilibrium stages, respectively, after the emulsion had been introduced into the 
reactor. The total volume of the gas phase $V^{\mathrm{G}}$ was calculated by the following relation in which the reactor volume $V_{\mathrm{R}}$ and the emulsion volume $V_{0}^{\mathrm{EM}}$ were known

$$
V^{\mathrm{G}}=V_{\mathrm{R}}-V_{0}^{\mathrm{EM}}
$$

According to eq 1 , by plotting the term $n_{j}^{\mathrm{EM}} M_{\mathrm{w}} / y_{j} \phi_{j}^{\mathrm{G}} p m_{0}^{\mathrm{EM}}$ as function of the overall initial mass fraction of cyclopentane in the emulsion $w_{\mathrm{CP}, 0}^{\mathrm{EM}}$, Henry's constants in the cyclopentane phase and in the water phase, $k_{\mathrm{H}, \mathrm{CO}_{2}, \mathrm{CP}}^{\mathrm{L}_{\mathrm{hc}}}\left(T, p_{\mathrm{CP}}^{\mathrm{o}, \sigma}\right)$ and $k_{\mathrm{H}, \mathrm{CO}_{2}, \mathrm{w}}^{\mathrm{L}_{\mathrm{w}}}\left(T, p_{\mathrm{w}}^{\mathrm{o}, \sigma}\right)$, respectively, could be derived. The average values of Henry's constants are presented in Table 3. Details about the calculation of their respective relative errors can be found in the supporting information.

Table 3. Experimental data on Henry's constant of $\mathrm{CO}_{2}$ in water $k_{\mathrm{H}, \mathrm{CO}_{2}, \mathrm{w}}^{\mathrm{L}_{\mathrm{w}}}\left(T, p_{\mathrm{w}}^{\mathrm{o}, \sigma}\right)$ and in cyclopentane $k_{\mathrm{H}, \mathrm{CO}_{2}, \mathrm{CP}}^{\mathrm{L}_{\mathrm{Cc}}}\left(T, p_{\mathrm{CP}}^{\mathrm{o}, \sigma}\right)$, respectively, as function of temperature $T^{\mathrm{a}}$.

\begin{tabular}{|ccc|}
\hline$T / \mathrm{K}$ & $k_{\mathrm{H}, \mathrm{CO}_{2}, \mathrm{w}}^{\mathrm{L}_{\mathrm{w}}}\left(T, p_{\mathrm{w}}^{\mathrm{o}, \sigma}\right) / \mathrm{MPa}$ & $k_{\mathrm{H}, \mathrm{CO}_{2}, \mathrm{CP}}^{\mathrm{L}_{\mathrm{hc}}}\left(T, p_{\mathrm{CP}}^{\mathrm{o}, \sigma}\right) / \mathrm{MPa}$ \\
\hline 278.3 & 79.9 & 9.3 \\
279.2 & 86.3 & 9.4 \\
280.2 & 90.5 & 9.6 \\
281.2 & 94.1 & 9.8 \\
282.2 & 97.5 & 10.0 \\
283.2 & 104.3 & 10.1 \\
284.2 & 108.7 & 10.3 \\
\hline
\end{tabular}

${ }^{a}$ Relative standard uncertainty in temperature $u_{\mathrm{r}}(T)=0.004$ and combined relative standard uncertainties in Henry's constants of $\mathrm{CO}_{2}$ in the two solvents $u_{\mathrm{c}, \mathrm{r}}\left(k_{\mathrm{H}, \mathrm{CO}_{2}, \mathrm{w}}^{\mathrm{L}_{\mathrm{w}}}\left(T, p_{\mathrm{w}}^{\mathrm{o}, \sigma}\right)\right)=0.110$ and $\left(u_{\mathrm{c}, \mathrm{r}}\left(k_{\mathrm{H}, \mathrm{CO}_{2}, \mathrm{CP}}^{\mathrm{L}_{\mathrm{cc}}}\left(T, p_{\mathrm{CP}}^{\mathrm{o}, \sigma}\right)\right)=0.116\right.$.

The $k_{\mathrm{H}, \mathrm{CO}_{2}, s}^{\pi}\left(T, p_{s}^{\mathrm{o}, \sigma}\right)$ data are, along with corresponding values calculated from correlations of Holder et al. ${ }^{28}$ and Sloan and Koh, ${ }^{1}$ plotted in the diagram of Figure 8. 


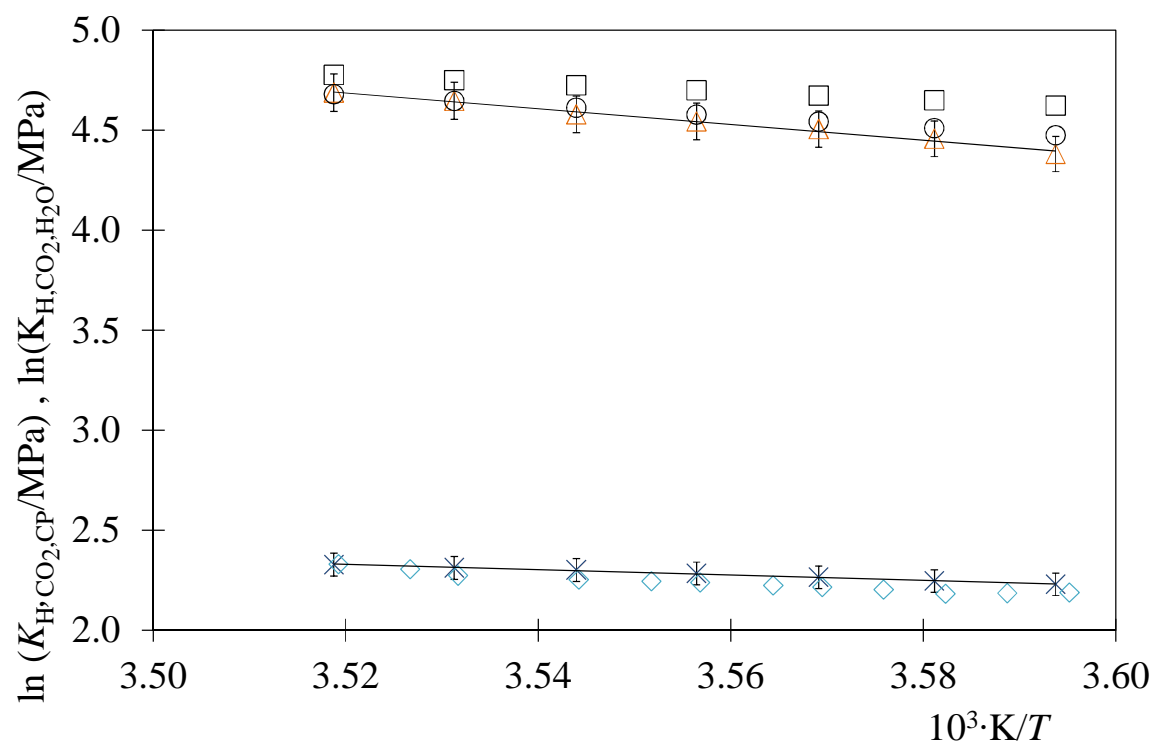

Figure 8. Experimental data and correlations of Henry's constant of carbon dioxide in water $k_{\mathrm{H}, \mathrm{CO}_{2}, \mathrm{w}}^{\mathrm{L}_{\mathrm{w}}}\left(T, p_{\mathrm{w}}^{\mathrm{o}, \sigma}\right)$ and in cyclopentane $k_{\mathrm{H}, \mathrm{CO}_{2}, \mathrm{CP}}^{\mathrm{L}_{\mathrm{c}}}\left(T, p_{\mathrm{CP}}^{\mathrm{o}, \sigma}\right)$ as function of the inverse temperature $T$. Data on Henry's constant of $\mathrm{CO}_{2}$ in water: $(\triangle)$ experimental results of this work, values calculated from correlations of $(\square)$ Holder et al., ${ }^{28}$ and (O) Sloan and Koh. ${ }^{1}$ Experimental data on Henry's constant of $\mathrm{CO}_{2}$ in cyclopentane, this work: $\mathrm{CP}$ as droplets in emulsion $(\times), \mathrm{CP}$ phase only $(\diamond) .(-)$ Empirical correlations.

The expression used for correlating Henry's constant $k_{\mathrm{H}, j, s}^{\pi}\left(T, p_{s}^{\mathrm{o}, \sigma}\right)$ for $\pi=\mathrm{L}_{\mathrm{w}}, \mathrm{L}_{\mathrm{hc}}$ with temperature was taken from an equation proposed by Holder et al. ${ }^{28}$

$$
k_{\mathrm{H}, j, s}^{\pi}\left(T, p_{s}^{\mathrm{o}, \sigma}\right) / \mathrm{MPa}=\exp \left(\lambda_{-1, j, s} \frac{1}{T}+\lambda_{0, j, s}\right) \text { for } \pi=\mathrm{L}_{\mathrm{w}}, \mathrm{L}_{\mathrm{hc}}
$$

By plotting the term $\ln \left(k_{\mathrm{H}, j, s}^{\pi}\left(T, p_{s}^{\mathrm{o}, \sigma}\right)\right)$ as function of $1 / T$ (see Figure 8), the empirical coefficients $\lambda_{0, j, s}$ and $\lambda_{-1, j, s}$ were obtained from the experimental data. They are compiled in Table 4 along with their respective relative uncertainties. 
Table 4. Coefficients for Henry's constant $k_{\mathrm{H}, j, s}^{\pi}$ correlation $^{28}$ with temperature $T$ according to eq $4^{\mathrm{a}}$.

\begin{tabular}{|c|c|c|c|c|c|}
\hline Gas $j$ & Solvent & Phase $\pi$ & {$\left[k_{\mathrm{H}, j, s}^{\pi}\right]$} & $\lambda_{0, j, s}$ & $\lambda_{-1, j, s} / \mathrm{K}$ \\
\hline $\mathrm{CO}_{2}$ & $\mathrm{H}_{2} \mathrm{O}$ & $\mathrm{L}_{\mathrm{w}}$ & $\mathrm{MPa}$ & 17.03 & -3509.07 \\
\hline $\mathrm{CO}_{2}$ & $\mathrm{CP}$ & $\mathrm{L}_{\mathrm{hc}}$ & $\mathrm{MPa}$ & 7.28 & -1407.44 \\
\hline
\end{tabular}
and $u_{\mathrm{c}, \mathrm{r}}\left(\lambda_{-1, \mathrm{CO}_{2}, \mathrm{CP}}\right)=0.038$.

For water, our data are found to be in good agreement with the data obtained from the correlation of Sloan and $\mathrm{Koh}^{1}$ (see Figure 8). However, they seem to deviate slightly from the values calculated by means of the parameters of Holder et al. ${ }^{28}$

For cyclopentane, we did not find a suitable correlation to compare our data with. However, experimentally we observed that the solubility of $\mathrm{CO}_{2}$ in pure $\mathrm{CP}$ is similar than the solubility of $\mathrm{CO}_{2}$ in $\mathrm{CP}$ droplets.

Establishing the data on Henry's constants of $\mathrm{CO}_{2}$ is essential for estimating the carbon dioxide solubility in the liquid phases (i.e, in cyclopentane and in water) at phase equilibrium, when the mixed $\mathrm{CO}_{2}+\mathrm{N}_{2}+\mathrm{CP}$ hydrate, the liquid phases and the gas phase coexist with each other. For nitrogen, due to the very low solubility of the gas in water, we did not succeed in measuring it experimentally. Hence, the correlation for Henry's constant of nitrogen in water, $k_{\mathrm{H}, \mathrm{N}_{2}, \mathrm{w}}^{\mathrm{L}_{\mathrm{w}}}(T, p)$, provided by Holder et al., ${ }^{28}$ was used to estimate the solubility. 
Experimental $\mathrm{H}-\mathrm{L}_{\mathrm{w}}-\mathrm{L}_{\mathrm{hc}}-\mathrm{G}$ equilibrium data involving a mixed cyclopentane + carbon dioxide + nitrogen hydrate phase

Mixed hydrate phase composition is defined through mass balance equations under the condition of $\mathrm{H}-\mathrm{L}_{\mathrm{w}}-\mathrm{L}_{\mathrm{hc}}-\mathrm{G}$ four phase equilibrium. Details on the mass balance calculations are provided in the supporting information. Briefly, the initial amount of substance of each gas $j$, $n_{j, 0}^{\mathrm{G}}\left(j=\mathrm{CO}_{2}\right.$ or $\left.\mathrm{N}_{2}\right)$, is known. After the emulsion had been introduced and a solid hydrate phase had been formed, four phases, the hydrate phase $(H)$, a liquid aqueous $\left(\mathrm{L}_{\mathrm{w}}\right)$, a liquid cyclopentane-rich organic $\left(\mathrm{L}_{\mathrm{hc}}\right)$ and a gas phase $(\mathrm{G})$ co-existed in the system. Under these conditions, the initial amounts of the two gases were distributed between these four phases. Hence, the following mass balance equation for gas amounts could be set up:

$$
n_{j, 0}^{\mathrm{G}}=n_{j}^{\mathrm{H}}+n_{j}^{\mathrm{EM}}+n_{j}^{\mathrm{G}} \quad\left(j=\mathrm{CO}_{2}, \mathrm{~N}_{2}\right)
$$

In eq $5, n_{j}^{\mathrm{H}}$ and $n_{j}^{\mathrm{G}}$ stand for the mole number of the gas $j$ in the hydrate phase and the gas phase, whereas $n_{j}^{\mathrm{EM}}=n_{j}^{\mathrm{L}_{\mathrm{w}}}+n_{j}^{\mathrm{L}_{\mathrm{hc}}}$ denotes the mole number of gas $j$ in the emulsion (organic phase dispersed in the aqueous phase). The mole number of species $j$ in the different phases in eq 5 was determined from mass balance considerations along with certain hypothesis (for further details it is referred to the supporting information). The complete set of experimentally derived equilibrium data, i.e. data on pressure $p$, temperature $T$, the mole fraction of $j\left(j=\mathrm{CO}_{2}\right.$ or $\left.\mathrm{N}_{2}\right)$ in the gas phase $y_{j}^{\prime}=n_{j}^{\mathrm{G}} /\left(n_{\mathrm{CO}_{2}}^{\mathrm{G}}+n_{\mathrm{N}_{2}}^{\mathrm{G}}\right)$ as well as in the mixed hydrate phase $z_{j}^{\prime}=n_{j}^{\mathrm{H}} /\left(n_{\mathrm{CO}_{2}}^{\mathrm{H}}+n_{\mathrm{N}_{2}}^{\mathrm{H}}\right)$ is reported in Table 5. 
Table 5. Experimental equilibrium data on the mole fraction $z_{j}^{\prime}$ of component $j$ in the mixed $\mathrm{CO}_{2}+\mathrm{N}_{2}+\mathrm{CP}$ - hydrate and the gas phase $y_{j}^{\prime a}$, respectively, at temperature $T$ and pressure $p$

\begin{tabular}{|cccccc|}
\hline$T / \mathrm{K}$ & $p / \mathrm{MPa}$ & $y_{\mathrm{CO}_{2}}^{\prime}$ & $y_{\mathrm{N}_{2}}^{\prime}$ & $z_{\mathrm{CO}_{2}}^{\prime}$ & $z_{\mathrm{N}_{2}}^{\prime}$ \\
\hline 283.5 & 0.761 & 0.279 & 0.721 & 0.728 & 0.272 \\
285.1 & 0.923 & 0.507 & 0.493 & 0.931 & 0.069 \\
285.2 & 0.766 & 0.769 & 0.231 & 0.999 & 0.001 \\
285.3 & 1.100 & 0.256 & 0.744 & 0.804 & 0.196 \\
285.8 & 1.94 & 0.081 & 0.919 & 0.395 & 0.605 \\
286.1 & 1.061 & 0.551 & 0.449 & 0.958 & 0.042 \\
286.1 & 0.866 & 0.791 & 0.209 & 0.988 & 0.012 \\
286.2 & 1.225 & 0.309 & 0.691 & 0.776 & 0.224 \\
286.3 & 2.18 & 0.126 & 0.874 & 0.549 & 0.451 \\
286.4 & 1.99 & 0.095 & 0.905 & 0.341 & 0.659 \\
287.2 & 2.20 & 0.136 & 0.864 & 0.513 & 0.487 \\
287.3 & 1.418 & 0.351 & 0.649 & 0.828 & 0.172 \\
287.5 & 1.130 & 0.836 & 0.164 & 1.000 & 0.000 \\
\hline
\end{tabular}

a Relative standard uncertainties $\mathrm{u}_{\mathrm{r}}$ are $u_{\mathrm{r}}(T)=0.004, u_{\mathrm{r}}(p)=0.005$ for $p>1.9 \mathrm{MPa}$ and $u_{\mathrm{r}}(p)=0.0017$ for $p<1.9$ MPa. Combined relative standard uncertainties $u_{\mathrm{c}, \mathrm{r}}\left(y_{j}^{\prime}\right)=0.0215$ and $u_{\mathrm{c}, \mathrm{r}}\left(z_{j}^{\prime}\right)=0.09$.

Gas selectivity

Figure 9 shows the "selectivity curve" in which for the system $\left\{\mathrm{H}_{2} \mathrm{O}+\mathrm{CP}+\mathrm{CO}_{2}+\mathrm{N}_{2}\right\}$ under the condition of $\mathrm{H}-\mathrm{L}_{\mathrm{w}}-\mathrm{L}_{\mathrm{hc}}-\mathrm{G}$ four phase equilibrium, the binary mole fraction of $\mathrm{CO}_{2}$ in the mixed $\mathrm{CO}_{2}+\mathrm{N}_{2}+\mathrm{CP}$ hydrate phase, $z_{\mathrm{CO}_{2}}^{\prime}=n_{\mathrm{CO}_{2}}^{\mathrm{H}} /\left(n_{\mathrm{CO}_{2}}^{\mathrm{H}}+n_{\mathrm{N}_{2}}^{\mathrm{H}}\right)$, is plotted against the binary mole fraction of $\mathrm{CO}_{2}$ in the gas phase $y_{\mathrm{CO}_{2}}^{\prime}=n_{\mathrm{CO}_{2}}^{\mathrm{G}} /\left(n_{\mathrm{CO}_{2}}^{\mathrm{G}}+n_{\mathrm{N}_{2}}^{\mathrm{G}}\right)$. This curve covers the temperature range from $283.5 \mathrm{~K}$ to $287.5 \mathrm{~K}$ and the pressure range from $0.76 \mathrm{MPa}$ to $2.23 \mathrm{MPa}$. In addition to the experimental data, Figure 9 shows corresponding curves calculated via a simulation for the system without cyclopentane, i.e. for the system $\left\{\mathrm{H}_{2} \mathrm{O}+\mathrm{CO}_{2}+\mathrm{N}_{2}\right\}$, by means of the in-house programme "GasHyDyn" ${ }^{23}$ at four different temperatures $T$. 


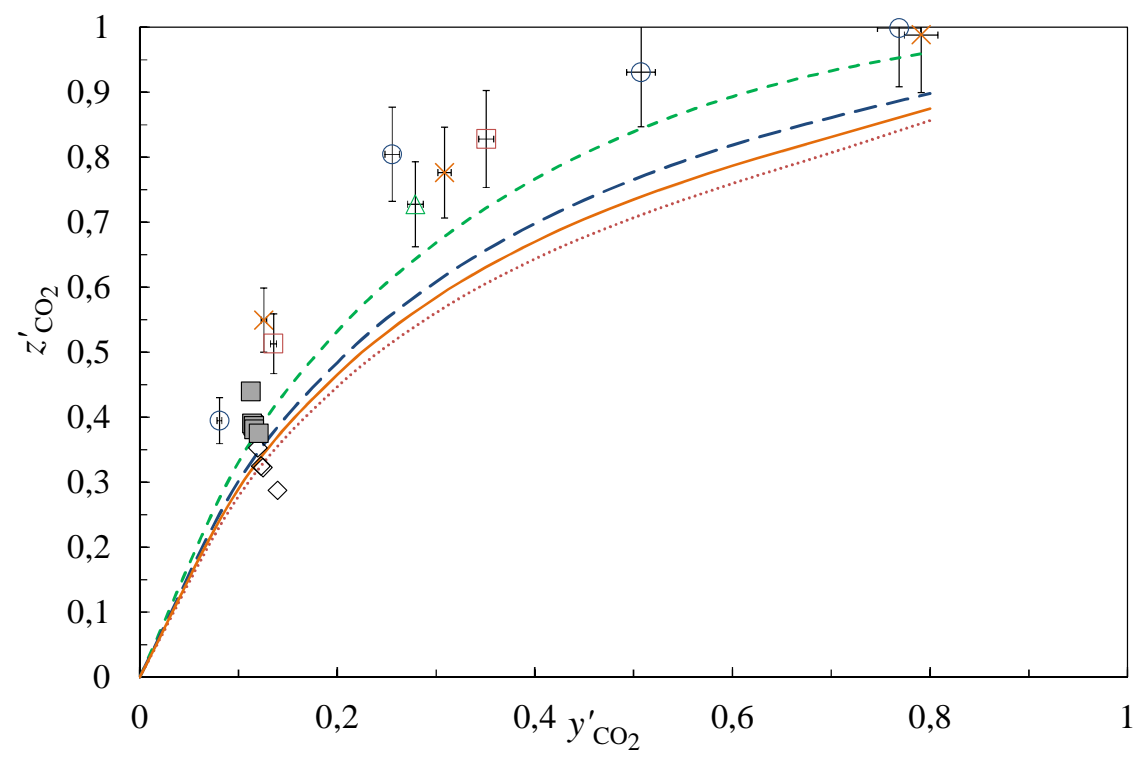

Figure 9. Mole fraction of $\mathrm{CO}_{2}$ in the hydrate phase $z_{\mathrm{CO}_{2}}^{\prime}$ as function of the corresponding mole fraction of $\mathrm{CO}_{2}$ in the gas phase $y_{\mathrm{CO}_{2}}^{\prime}$, both at equilibrium, for different temperatures $T$ between 282.5 K to 287.5 K. Symbols correspond to experimental data at $(\triangle) 282.5 \mathrm{~K}$, ( $\bigcirc) 285.3 \mathrm{~K},(\times)$ 286.2 K and $(\square) 287.3 \mathrm{~K}$. Literature data of Li et al..$^{22}$ for $(\diamond)$ emulsion system, and $(\square)$ system containing two "macroscopic" liquid phases. Simulations obtained by means of the in-house software "GasHyDyn",23 for the corresponding system without cyclopentane at (-----) $282.5 \mathrm{~K}$, $(---) 285.3 \mathrm{~K},(-) 286.2 \mathrm{~K}$ and $(\cdots \cdots) 287.3 \mathrm{~K}$.

It can be seen in Figure 9 that the carbon dioxide selectivity in the mixed $\mathrm{CO}_{2}+\mathrm{N}_{2}+\mathrm{CP}$ hydrates is significantly increased compared to the theoretical selectivity of the gas hydrates without any promoter. For example, the mole fraction of $\mathrm{CO}_{2}$ relative to the system $\left\{\mathrm{CO}_{2}+\mathrm{N}_{2}\right\}$ present in the hydrate phase $z_{\mathrm{CO}_{2}}^{\prime}$ approaches 0.931 for a corresponding mole fraction of $\mathrm{CO}_{2}$ in the gas phase $y_{\mathrm{CO}_{2}}^{\prime}$ of 0.507 .

Experimental data presented by $\mathrm{Li}$ et al. ${ }^{22}$ for mixed $\mathrm{CO}_{2}+\mathrm{N}_{2}+\mathrm{CP}$ hydrates are added in Figure 9. Li et al. ${ }^{22}$ performed experiments on the system $\left\{\mathrm{H}_{2} \mathrm{O}+\mathrm{CO}_{2}+\mathrm{N}_{2}+\mathrm{CP}\right\}$ in two 
different ways. Firstly, the authors carried out measurements on the system in which cyclopentane appear in the form of an emulsion in water. Secondly, cyclopentane as a clear separated phase from water has been studied. The feed gas contains a $\mathrm{CO}_{2}$ mole fraction of 0.166. This initial $\mathrm{CO}_{2}$ mole fraction drops to around 0.12 after crystallisation. It needs to be underlined that their data are calculated from a gas uptake measurement. Therefore, there is no distinction between the mixed $\mathrm{CO}_{2}+\mathrm{N}_{2}+\mathrm{CP}$ hydrate phase and the liquid phases. The temperature is fixed at $281.25 \mathrm{~K}$ and the equilibrium pressures are ranging from $2.49 \mathrm{MPa}$ to 3.95 MPa. Li et al. ${ }^{22}$ have observed differences in the gas uptake depending on the mesoscopic state of the solution, i.e., depending on whether it exists in the form of an emulsion, or as two separated macroscopic phases. If one takes a look at their data, the respective values are higher than the nitrogen or carbon dioxide equilibrium pressure (see Figure 10). Besides, some data are in the stability zone of the gas hydrate phase formed with carbon dioxide only. Thus, the formation of carbon dioxide gas hydrate might occur during the crystallisation procedure and the presence of two types of hydrates $\left(\mathrm{CO}_{2}\right.$ gas hydrates and mixed hydrates of $\left.\mathrm{CP}+\mathrm{CO}_{2}+\mathrm{N}_{2}\right)$ might be realistic. Hence, it can be argued that the data of $\mathrm{Li}$ et al. ${ }^{22}$ are not at equilibrium and cannot directly be compared to the data presented in this work. 


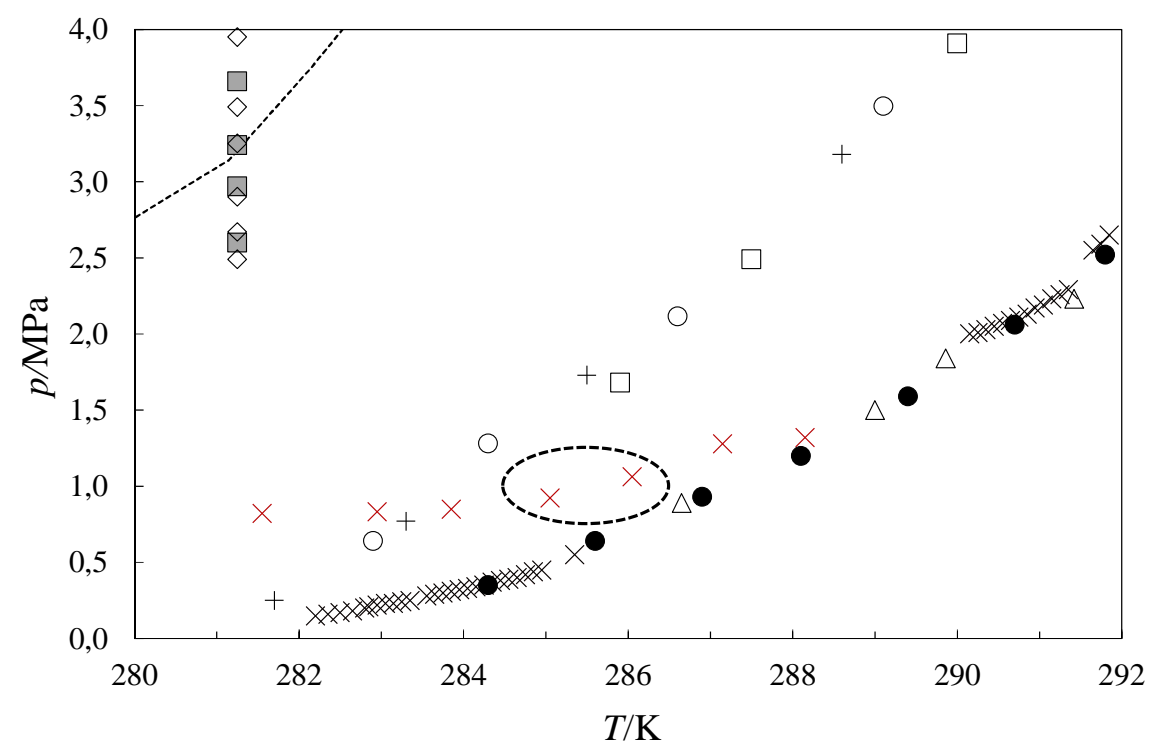

Figure 10. $\mathrm{H}-\mathrm{L}_{\mathrm{w}}-\mathrm{L}_{\mathrm{hc}}-\mathrm{G}$ or $\mathrm{H}-\mathrm{L}_{\mathrm{w}}-\mathrm{G} p$-T-equilibrium dissociation data for systems with and without cyclopentane. Symbols corresponding to experimental data. $\mathrm{CO}_{2}+\mathrm{CP}$ mixed hydrates: data of $(\times)$ Galfré et al. ${ }^{29},(\triangle)$ Zhang and Lee ${ }^{15}$, Zhang et al. ${ }^{16}$ and $(\bullet)$ Mohammadi and Richon $(2009)^{18} ; \mathrm{N}_{2}+\mathrm{CP}$ mixed hydrates: $(\bigcirc)$ data of Tohidi et al. ${ }^{19},(\square)$ Du et al. ${ }^{20}$ and $(+)$ Mohammadi and Richon $(2011)^{21} ; \mathrm{CO}_{2}+\mathrm{N}_{2}+\mathrm{CP}$ mixed hydrates: $(\times)$ this work; data of Li et al. $^{22}$ for $(\diamond)$ emulsion system and $(\square)$ system containing two "macroscopic" liquid phases. (----) Simulations obtained with the in-house programme "GasHyDyn" 23 for carbon dioxide gas hydrates. The two encircled data points correspond to two points of dissociation of the hydrate phase.

The $\mathrm{H}-\mathrm{L}_{\mathrm{w}}-\mathrm{L}_{\mathrm{hc}}-\mathrm{G} p-T$ equilibrium data on the system exhibiting a $\mathrm{CO}_{2}+\mathrm{N}_{2}+\mathrm{CP}$ mixed hydrate phase which are displayed in Figure 10 were obtained during the dissociation procedure (Figure 7). The change in the slope of the pressure versus temperature curve at $284 \mathrm{~K}$ characterises the beginning of the dissociation. The repeated change in the slope of the same 
curve at $287 \mathrm{~K}$ characterises the end of the dissociation. The two encircled data points correspond to two points of dissociation. These points are presented in Table 5.

Equilibrium pressure

The $\mathrm{H}-\mathrm{L}_{\mathrm{w}}-\mathrm{L}_{\mathrm{hc}}-\mathrm{G}$ equilibrium pressure of the mixed $\mathrm{CO}_{2}+\mathrm{N}_{2}+\mathrm{CP}$ hydrate plotted against the composition of the $\mathrm{CO}_{2}+\mathrm{N}_{2}$ gas phase in terms of $y_{\mathrm{CO}_{2}}^{\prime}$ is shown in Figure 11. Equilibrium $p$ $y_{\mathrm{CO}_{2}}^{\prime}$-curves obtained from a simulation of the $\mathrm{H}-\mathrm{L}_{\mathrm{w}}-\mathrm{G}$ equilibrium on the system $\left\{\mathrm{H}_{2} \mathrm{O}+\mathrm{CO}_{2}\right.$ $\left.+\mathrm{N}_{2}\right\}^{23}$ by means of the in-house programme "GasHyDyn" are shown for comparison in Figure 11.

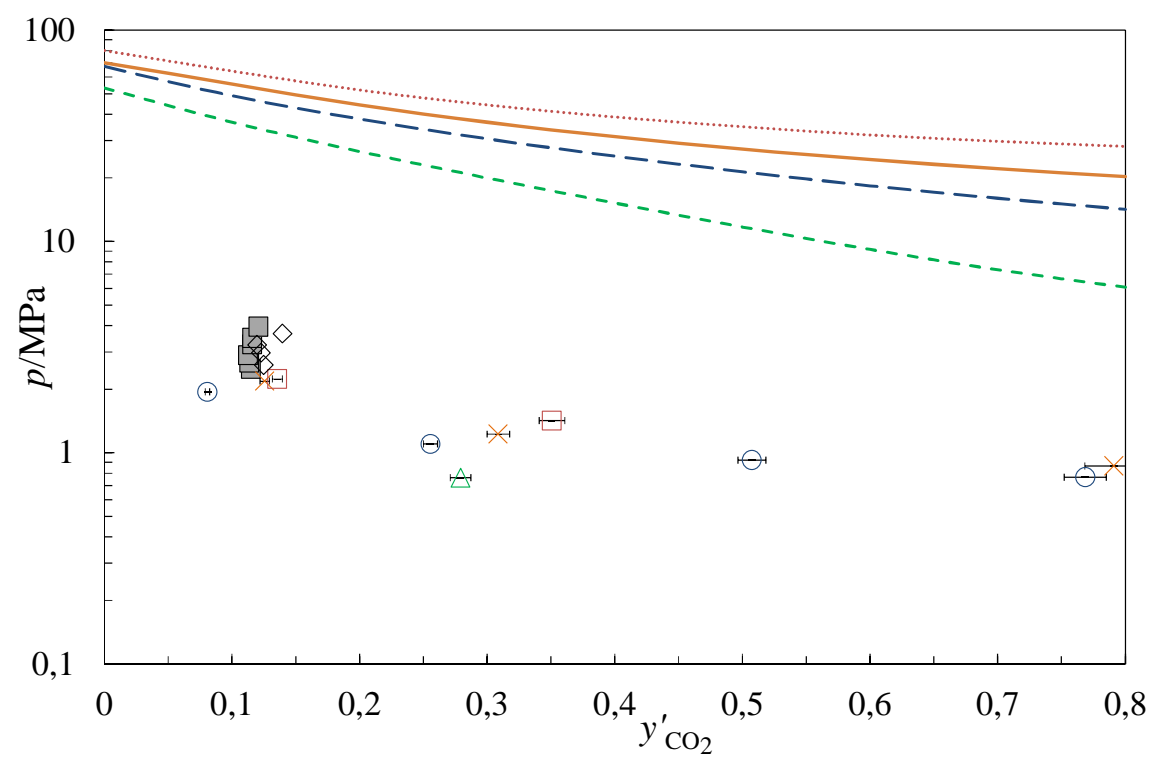

Figure 11. Gas hydrate $\mathrm{H}-\mathrm{L}_{\mathrm{w}}-\mathrm{L}_{\mathrm{hc}}-\mathrm{G}$ equilibrium pressure $p$ as function of the corresponding mole fraction of $\mathrm{CO}_{2}$ in the gas phase $y_{\mathrm{CO}_{2}}^{\prime}$ in the temperature range $T$ from $282.8 \mathrm{~K}$ to $287.5 \mathrm{~K}$. Symbols correspond to experimental data: $(\triangle) 282.5 \mathrm{~K},(\bigcirc) 285.3 \mathrm{~K},(\times) 286.2 \mathrm{~K},(\square) 287.3 \mathrm{~K}$. Literature data of Li et al. ${ }^{22}$ for $(\diamond)$ (emulsion system) and $(\square)$ (system containing two "macroscopic" liquid phases). Simulations on the $\mathrm{H}-\mathrm{L}_{\mathrm{w}}-\mathrm{G}$ equilibrium for the corresponding 
system without cyclopentane at $282.5 \mathrm{~K}(----), 285.3 \mathrm{~K}(---), 286.2 \mathrm{~K}(-)$ and $287.3 \mathrm{~K}(\cdots \cdot)$ obtained by means of the in-house "GasHyDyn" software. ${ }^{23}$

Compared with the calculated equilibrium pressure for mixed $\mathrm{CO}_{2}+\mathrm{N}_{2}$-gas hydrates formed in the system without any promoter, the equilibrium pressure is drastically decreased for the system in which cyclopentane is additionally present. Quantitatively, the pressure reduction factor $F$ defined in eq 6 does assume values ranging from 19 to 34, corresponding to a relative pressure reduction of 0.95 up to 0.97 .

$$
F=\frac{p_{\text {eq, cal }}^{\mathrm{H}-\mathrm{L}_{\mathrm{w}}-\mathrm{G}}}{p_{\mathrm{eq}, \exp }^{\mathrm{H}-\mathrm{L}_{\mathrm{w}}-\mathrm{L}_{\mathrm{hc}}-\mathrm{G}}}
$$

In eq $6, p_{\mathrm{eq}, \mathrm{cal}}^{\mathrm{H} \mathrm{L}_{\mathrm{w}} \mathrm{G}}$ is the equilibrium pressure estimated by means of the in-house "GasHyDyn"programme for gas hydrates formed in the ternary system $\left\{\mathrm{H}_{2} \mathrm{O}+\mathrm{CO}_{2}+\mathrm{N}_{2}\right\} \cdot p_{\text {eq,exp }}^{\mathrm{H}-\mathrm{L}_{\mathrm{w}}-\mathrm{L}_{\mathrm{hc}}-\mathrm{G}}$ is the equilibrium pressure measured for the four phase $H-L_{w}-L_{h c}-G$ equilibrium in the quaternary system $\left\{\mathrm{H}_{2} \mathrm{O}+\mathrm{CP}+\mathrm{CO}_{2}+\mathrm{N}_{2}\right\}$ exhibiting a mixed $\mathrm{CO}_{2}+\mathrm{N}_{2}+\mathrm{CP}$ - hydrate phase.

\section{Gas storage capacity}

In order to illustrate how much of gas, expressed in terms of its volume under defined $p$ - $T$-state conditions, is incorporated into the hydrate structure, the so-called gas storage capacity GSC is introduced. The gas storage capacity of gas hydrates is defined as the ratio of the volume of the total amount of gas which is consumed in order to form the hydrate phase $V_{\mathrm{CO}_{2}+\mathrm{N}_{2}}^{\mathrm{G}}\left(T_{\text {ref }}, p_{\text {ref }}, n_{\mathrm{CO}_{2}}^{\mathrm{H}}, n_{\mathrm{N}_{2}}^{\mathrm{H}}\right)$, normalised to reference state conditions of $T_{\text {ref }}=273.15 \mathrm{~K}$ and $p_{\text {ref }}=0.101325 \mathrm{MPa}$, and the corresponding volume of the gas hydrate phase $V^{\mathrm{H}}$ by which the gases along with cyclopentane are captured. $V_{\mathrm{CO}_{2}+\mathrm{N}_{2}}^{\mathrm{G}}$ can be expressed by means of the mole 
numbers of the enclathrated gases, $n_{\mathrm{CO}_{2}}^{\mathrm{H}}$ and $n_{\mathrm{N}_{2}}^{\mathrm{H}}$, that have previously been consumed from the gas phase upon hydrate formation, and the molar volume of the gas phase under reference conditions. The gas phase, consisting in good approximation of $\mathrm{CO}_{2}$ and $\mathrm{N}_{2}$ only, has a molar volume under reference conditions of $V_{\mathrm{m}, \mathrm{CO}_{2}+\mathrm{N}_{2}}^{\mathrm{G}}\left(T_{\text {ref }}, p_{\text {ref }}, y_{\mathrm{CO}_{2}}\right)$, which will in the following be abbreviated as $V_{\mathrm{m}, \mathrm{CO}_{2}+\mathrm{N}_{2} \text {, ref }}^{\mathrm{G}}$. The value of $V_{\mathrm{m}, \mathrm{CO}_{2}+\mathrm{N}_{2} \text {, ref }}^{\mathrm{G}}$ is estimated by means of the SoaveRedlich-Kwong equation of state and is close to the ideal gas value of approximately $22.4 \mathrm{dm}^{3} \cdot \mathrm{mol}^{-1}$. The volume of the hydrate phase $V^{\mathrm{H}}$ can be also expressed by means of the molar volume of the hydrate phase, $V_{\mathrm{m}}^{\mathrm{H}}$, and the corresponding mole numbers of the constituents present in the solid phase $n_{\mathrm{w}}^{\mathrm{H}}, n_{\mathrm{CP}}^{\mathrm{H}}, n_{\mathrm{CO}_{2}}^{\mathrm{H}}$ and $n_{\mathrm{N}_{2}}^{\mathrm{H}}$. Thus, the expression for $G S C$ reads:

$$
G S C=\frac{V_{\mathrm{CO}_{2}+\mathrm{N}_{2}}^{\mathrm{G}}\left(T_{\mathrm{ref}}, p_{\mathrm{ref}}, n_{\mathrm{CO}_{2}}^{\mathrm{H}}, n_{\mathrm{N}_{2}}^{\mathrm{H}}\right)}{V^{\mathrm{H}}}=\frac{\left(n_{\mathrm{CO}_{2}}^{\mathrm{H}}+n_{\mathrm{N}_{2}}^{\mathrm{H}}\right) V_{\mathrm{m}, \mathrm{CO}_{2}+\mathrm{N}_{2}, \text { ref }}^{\mathrm{G}}}{\left(n_{\mathrm{w}}^{\mathrm{H}}+n_{\mathrm{CP}}^{\mathrm{H}}+n_{\mathrm{CO}_{2}}^{\mathrm{H}}+n_{\mathrm{N}_{2}}^{\mathrm{H}}\right) V_{\mathrm{m}}^{\mathrm{H}}}
$$

As a non-stoichiometric solid, the hydrate phase is to be regarded as a solid solution of the guest components in the metastable host lattice. ${ }^{30}$ Therefore, as a property of a mixed phase, $V_{\mathrm{m}}^{\mathrm{H}}$ does also depend on composition. It can be estimated from crystallographic data of the sII unit cell by means of the following relation ${ }^{1}$

$$
V_{\mathrm{m}}^{\mathrm{H}}=\frac{V_{\mathrm{uc}}^{\mathrm{H}} N_{\mathrm{Av}}}{N_{\mathrm{w}, \mathrm{uc}}^{\mathrm{H}}\left(1+v_{\mathrm{sm}}\left(\theta_{\mathrm{CP} s \mathrm{~m}}^{\mathrm{H}}+\theta_{\mathrm{CO}_{2} \mathrm{sm}}^{\mathrm{H}}+\theta_{\mathrm{N}_{2} \mathrm{sm}}^{\mathrm{H}}\right)+v_{\mathrm{lg}}\left(\theta_{\mathrm{CP}_{\mathrm{g}}}^{\mathrm{H}}+\theta_{\mathrm{CO}_{2} \text { lg }}^{\mathrm{H}}+\theta_{\mathrm{N}_{2} \text { lg }}^{\mathrm{H}}\right)\right)}
$$

where $N_{\mathrm{w}, \mathrm{uc}}^{\mathrm{H}}$ designates the number of water molecules in the unit cell. $v_{i}$ is the number of cavities of type $i$ per water molecule in the corresponding unit cell $(i \in\{\mathrm{sm}, \lg \}$, with "sm" indicating the small and "lg" the large cavity, respectively, and $v_{\mathrm{sm}}=2 / 17$ and $v_{\mathrm{lg}}=1 / 17$ for sII hydrates). $\theta_{j i}^{\mathrm{H}}$ is the occupancy factor of cavity $i$ by guest molecule $j\left(j \in\left\{\mathrm{CP}, \mathrm{CO}_{2}, \mathrm{~N}_{2}\right\}\right)$. $N_{\mathrm{Av}}=6.02214129(27) \times 10^{23} \mathrm{~mol}^{-1}$ is Avogadro's constant. ${ }^{27} V_{\mathrm{uc}}^{\mathrm{H}}$ denotes the volume of the unit 
cell of sII clathrate hydrate which can be calculated from its corresponding lattice parameter $a_{\mathrm{uc}}$ according to:

$$
V_{\mathrm{uc}}^{\mathrm{H}}=a_{\mathrm{uc}}^{3}
$$

The numerical value for the cell parameter provided in the monograph of Sloan and Koh ${ }^{1}$, $a_{\mathrm{uc}}=1.73 \mathrm{~nm}$, is a typical average value and used in this study as well. The occupancy factors $\theta_{j \mathrm{sm}}^{\mathrm{H}}$ and $\theta_{j \mathrm{lg}}^{\mathrm{H}}$ and the number of guest molecules $j$ enclathrated in the unit cell, $N_{j, \mathrm{uc}}^{\mathrm{H}}$, are related by

$$
N_{j, \mathrm{uc}}^{\mathrm{H}}=N_{j \mathrm{sm}, \mathrm{uc}}^{\mathrm{H}}+N_{j \mathrm{lg}, \mathrm{uc}}^{\mathrm{H}}=N_{\mathrm{w}, \mathrm{uc}}^{\mathrm{H}}\left(v_{\mathrm{sm}} \theta_{j \mathrm{sm}}^{\mathrm{H}}+v_{\mathrm{lg}} \theta_{j \mathrm{lg}}^{\mathrm{H}}\right) \quad j \in\left\{\mathrm{CP}, \mathrm{CO}_{2}, \mathrm{~N}_{2}\right\}
$$

Since at equilibrium the concentration of a given species in the unit cell is identical to the concentration in the macroscopic hydrate crystal, the ratio between $N_{k \text {, uc }}^{\mathrm{H}}$ and $n_{\mathrm{k}}^{\mathrm{H}}$, the mole number of species $k$ in the macroscopic crystal, is constant for all $k \in\left\{\mathrm{w}, \mathrm{CP}, \mathrm{CO}_{2}, \mathrm{~N}_{2}\right\}$.

$$
\frac{n_{\mathrm{w}}^{\mathrm{H}}}{N_{\mathrm{w}, \mathrm{uc}}^{\mathrm{H}}}=\frac{n_{\mathrm{CP}}^{\mathrm{H}}}{N_{\mathrm{CP} \text {, uc }}^{\mathrm{H}}}=\frac{n_{\mathrm{CO}_{2}}^{\mathrm{H}}}{N_{\mathrm{CO}_{2}, \text { uc }}^{\mathrm{H}}}=\frac{n_{\mathrm{N}_{2}}^{\mathrm{H}}}{N_{\mathrm{N}_{2}, \text { uc }}^{\mathrm{H}}}
$$

By substituting $V_{\mathrm{m}}^{\mathrm{H}}$ in eq 7 for the general expression given in eq 8 and taking into account eqs 10 and 11 the following equation is derived for $G S C$

$$
G S C=\frac{N_{\mathrm{w}, \mathrm{uc}}^{\mathrm{H}}\left(n_{\mathrm{CO}_{2}}^{\mathrm{H}}+n_{\mathrm{N}_{2}}^{\mathrm{H}}\right) V_{\mathrm{m}, \mathrm{CO}_{2}+\mathrm{N}_{2}, \text { ref }}^{\mathrm{G}}}{n_{\mathrm{w}}^{\mathrm{H}} V_{\mathrm{uc}}^{\mathrm{H}} N_{\mathrm{Av}}}
$$

Eq 12 expresses the gas storage capacity in terms of the experimentally accessible quantities $n_{\mathrm{w}}^{\mathrm{H}}, n_{\mathrm{CO}_{2}}^{\mathrm{H}}$ and $n_{\mathrm{N}_{2}}^{\mathrm{H}}$. From this relation, the GSC values obtained from the experimental data were calculated. Alternatively, by again combining eq 7 with eqs 8,10 and 11, the gas storage capacity can be expressed by means of the occupancy factors of the two gases as

$$
G S C=\frac{N_{\mathrm{w}, \mathrm{uc}}^{\mathrm{H}} V_{\mathrm{m}, \mathrm{CO}_{2}+\mathrm{N}_{2}, \text { ref }}^{\mathrm{G}}\left(\nu_{\mathrm{sm}}\left(\theta_{\mathrm{CO}_{2}, \mathrm{sm}}^{\mathrm{H}}+\theta_{\mathrm{N}_{2}, \mathrm{sm}}^{\mathrm{H}}\right)+v_{\mathrm{lg}}\left(\theta_{\mathrm{CO}_{2}, \mathrm{lg}}^{\mathrm{H}}+\theta_{\mathrm{N}_{2}, \mathrm{lg}}^{\mathrm{H}}\right)\right)}{V_{\mathrm{uc}}^{\mathrm{H}} N_{\mathrm{Av}}}
$$


In Figure 12, the gas storage capacity GSC for mixed hydrates is plotted against the composition of the $\mathrm{CO}_{2}+\mathrm{N}_{2}$ gas phase in terms of $y_{\mathrm{CO}_{2}}^{\prime}$. In this diagram, it can be seen that the GSC is in the range of $(20-60) \mathrm{m}^{3}$ gas. $\mathrm{m}^{-3}$ hydrate (Table 6), scattered around a mean value of 40 $\mathrm{m}^{3}$ gas. $\mathrm{m}^{-3}$ hydrate with a precision of 0.06 (see supporting information for details).

The GSC-data derived by means of eq 12 can be compared to different limiting values for this quantity. The first hypothetical limit is derived under the condition that the 16 small cavities are completely occupied by gas molecules while the large cavities are assumed to be occupied by CP-species only. Under these conditions, mathematically expressed by $\theta_{\mathrm{CO}_{2} \mathrm{sm}}^{\mathrm{H}}+\theta_{\mathrm{N}_{2} \mathrm{sm}}^{\mathrm{H}}=1$ and $\theta_{\mathrm{CPlg}}^{\mathrm{H}}=1 \Leftrightarrow \theta_{\mathrm{CO}_{2} \mathrm{lg}}^{\mathrm{H}}+\theta_{\mathrm{N}_{2} \mathrm{lg}}^{\mathrm{H}}=0$, the limiting value $G S C_{\mathrm{lim}, 1}$ obtained from eq 13 is given by

$$
G S C_{\mathrm{lim}, 1}=G S C\left(\theta_{\mathrm{CO}_{2} \mathrm{sm}}^{\mathrm{H}}+\theta_{\mathrm{N}_{2} \mathrm{sm}}^{\mathrm{H}}=\theta_{\mathrm{CPlg}}^{\mathrm{H}}=1\right)=\frac{N_{\mathrm{w}, \mathrm{uc}}^{\mathrm{H}} \nu_{\mathrm{sm}} V_{\mathrm{m}}^{\mathrm{G}}\left(T_{\mathrm{ref}}, p_{\mathrm{ref}}, y_{\mathrm{CO}_{2}}\right)}{V_{\mathrm{uc}}^{\mathrm{H}} N_{\mathrm{Av}}}
$$

which leads to a numerical value of $115 \mathrm{~m}^{3}$ gas. $\mathrm{m}^{-3}$ hydrate. The $G S C$-values derived from the experimental results should further be compared to a second hypothetical limiting value, $G S C_{\lim , 2}$, calculated for the condition that all of the cavities are completely occupied by gas molecules only. In this case, characterised by $\theta_{\mathrm{CO}_{2} \mathrm{sm}}^{\mathrm{H}}+\theta_{\mathrm{N}_{2} \mathrm{sm}}^{\mathrm{H}}=1$ and $\theta_{\mathrm{CO}_{2} \mathrm{lg}}^{\mathrm{H}}+\theta_{\mathrm{N}_{2} \mathrm{lg}}^{\mathrm{H}}=1$, the following relation is derived from eq 13

$G S C_{\lim , 2}=G S C\left(\theta_{\mathrm{CO}_{2} \mathrm{sm}}^{\mathrm{H}}+\theta_{\mathrm{N}_{2} \mathrm{sm}}^{\mathrm{H}}=\theta_{\mathrm{CO}_{2} \mathrm{lg}}^{\mathrm{H}}+\theta_{\mathrm{N}_{2} \mathrm{lg}}^{\mathrm{H}}=1\right)=\frac{N_{\mathrm{w}, \mathrm{uc}}^{\mathrm{H}}\left(v_{\mathrm{sm}}+v_{\mathrm{lg}}\right) V_{\mathrm{m}}^{\mathrm{G}}\left(T_{\mathrm{ref}}, p_{\mathrm{ref}}, y_{\mathrm{CO}_{2}}\right)}{V_{\mathrm{uc}}^{\mathrm{H}} N_{\mathrm{Av}}}$

which leads to $G S C_{\lim , 2}=172.41 \mathrm{~m}^{3}$ gas. $\mathrm{m}^{-3}$ hydrate .

Consequently, the GSC-value derived from our results for the system with $\mathrm{CP}$ is smaller by around 0.65 and 0.77 compared to the hypothetical bounds set by $G S C_{\lim , 1}$ and $G S C_{\lim , 2}$. It is noted that the value of $40 \mathrm{~m}^{3}$ gas. $\mathrm{m}^{-3}$ hydrate was also measured by Duc et al. ${ }^{2}$ on systems based 
on a different type of hydrates, the so-called (gas-) semi-clathrate hydrates, which can be formed when tetra- $n$-butyl ammonium bromide is additionally dissolved in the aqueous phase.

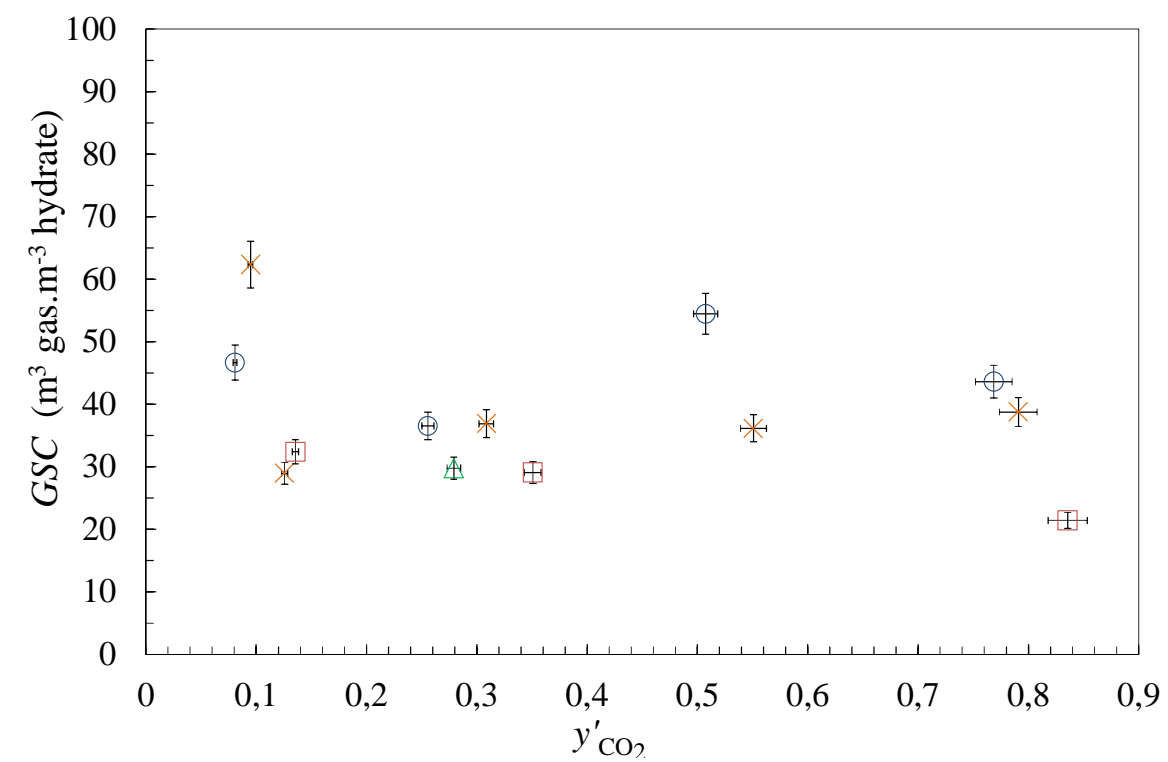

Figure 12. Gas storage capacity GSC for $\mathrm{CO}_{2}+\mathrm{N}_{2}$ gas mixtures from $282.5 \mathrm{~K}$ to $287.5 \mathrm{~K}$ as function of the mole fraction of $\mathrm{CO}_{2}$ in the gas phase $y_{\mathrm{CO}_{2}}^{\prime}$ (with respect to the total amount of $\mathrm{CO}_{2}+\mathrm{N}_{2}$, i.e., $y_{\mathrm{CO}_{2}}^{\prime}+y_{\mathrm{N}_{2}}^{\prime}=1$ ). Symbols correspond to experimental data at $(\triangle) 282.5 \mathrm{~K},(\bigcirc)$ $285.3 \mathrm{~K},(\times) 286.2 \mathrm{~K},(\square) 287.3 \mathrm{~K}$. 
Table 6. Experimental equilibrium values of $G S C$ at corresponding gas mole fraction of $\mathrm{CO}_{2}$ $y_{\mathrm{CO}_{2}}^{\prime}$ and temperature $T^{\mathrm{a}}$.

\begin{tabular}{|ccc|}
\hline$T / \mathrm{K}$ & $y_{\mathrm{CO}_{2}}^{\prime}$ & $\mathrm{GSC} / \mathrm{m}^{3}$ gas.m ${ }^{-3}$ hydrate \\
\hline 283.5 & 0.279 & 29.8 \\
285.1 & 0.507 & 54.5 \\
285.2 & 0.769 & 43.6 \\
285.3 & 0.256 & 36.5 \\
285.8 & 0.081 & 46.7 \\
286.1 & 0.551 & 36.2 \\
286.1 & 0.791 & 38.8 \\
286.2 & 0.309 & 36.9 \\
286.3 & 0.126 & 29.0 \\
286.4 & 0.095 & 62.3 \\
287.2 & 0.136 & 32.4 \\
287.3 & 0.351 & 29.1 \\
287.5 & 0.836 & 21.4 \\
\hline
\end{tabular}

${ }^{\text {a }}$ The relative standard uncertainty $u_{\mathrm{r}}(T)$ amounts to $u_{\mathrm{r}}(T)=0.004$. The combined relative standard uncertainties for $y_{\mathrm{CO}_{2}}^{\prime}$ and GSC are $u_{\mathrm{c}, \mathrm{r}}\left(y_{\mathrm{CO}_{2}}^{\prime}\right)=0.0215$ and $u_{\mathrm{c}, \mathrm{r}}(G S C)=0.06$.

The low occupancy of the hydrate lattice sites by the molecules of $\mathrm{CO}_{2}$ and $\mathrm{N}_{2}$ may be due to the fact that the stabilisation by cyclopentane molecules is very efficient and does not require a greater amount of additional gas to stabilise the structure. Contrary to our experimental results (Table 6), Li et al. ${ }^{31}$ did not observe $\mathrm{CO}_{2}$ molecules enclathrated in the different cavities of the sII hydrate structure via x-Ray analysis. However, their experiments were performed at $276.15 \mathrm{~K}$, i.e. at a temperature which is below the formation temperature of pure cyclopentane hydrate, located at $280.22 \mathrm{~K} .{ }^{14}$ In this temperature zone, Herslund et al. ${ }^{32}$ demonstrated that there is a competition between the formation of gas-cyclopentane hydrate and the pure cyclopentane hydrate, the latter of which being the more rapid process.

In the experimental study of $\mathrm{Li}$ et al. ${ }^{31}$ for example, cyclopentane molecules might have predominantly dissolved in the mixed hydrate phase obtained in their measurements. In other 
words, the solid phase generated by the authors might actually constitute pure cyclopentane hydrate only which appears to be the most plausible explanation why they did not observe carbon dioxide in the hydrate structure. Therefore, experimental investigations on the formation of mixed gas $+\mathrm{CP}$ hydrates have to be carried out at a temperature above the temperature of pure cyclopentane hydrate formation. At those temperatures, trapping of $\mathrm{CO}_{2}$ and $\mathrm{N}_{2}$ is observed although the GSC is rather low.

\section{Conclusions}

An experimental method has been presented by which the phase equilibrium between a binary gas mixture, a solid hydrate phase, a liquid aqueous phase and a liquid CP-rich organic phase in the quaternary system $\left\{\mathrm{H}_{2} \mathrm{O}+\mathrm{CP}+\mathrm{CO}_{2}+\mathrm{N}_{2}\right\}$ was investigated. By this method, a phase diagram could be established in which the mole fraction of $\mathrm{CO}_{2}$ in the gas phase is plotted against the mole fraction of $\mathrm{CO}_{2}$ in the hydrate phase, both defined with respect to total amount of $\mathrm{CO}_{2}$ and $\mathrm{N}_{2}$ in the respective phase.

Measurements have been carried out to generate data on the hydrate equilibrium from a $\mathrm{CO}_{2}+\mathrm{N}_{2}$ gas mixture of fixed initial composition in presence of a thermodynamic promoter (cyclopentane) dispersed as an emulsion. Three principal conclusions can be drawn. Firstly, the selectivity of the hydrate based $\mathrm{CO}_{2}$ capture process using cyclopentane as a promoter is improved in comparison to the corresponding hydrate process based on the system without promoter. Secondly, the equilibrium pressure is drastically reduced (a drop of pressure by 0.95 up to 0.97 is observed). Unfortunately, the gas storage capacity is lowered as well. Cyclopentane, which is a very good hydrate former, seems to stabilise the cavities in such a way that it prevents the complete occupation of the remaining cavities by gas molecules. 
Acknowledgements

This work has been supported by the FUI-ACACIA ("Amélioration du Captage du $\mathrm{CO}_{2}$ Industriel et Anthropique") project in the framework of the AXELERA cluster and the European ICAP project (Innovative $\mathrm{CO}_{2} \mathrm{CAPture}$ ). The authors are particularly grateful to the members of the technical staff at Ecole Nationale Supérieure des Mines des Saint-Etienne: Alain Lallemand, Fabien Chauvy, Marie Claude Bartholin and Jean Pierre Poyet.

References

(1) Sloan, D. E.; Koh, C. A. Clathrate Hydrates of Natural Gases, 3rd Revised edition. CRC Press Inc, 2007.

(2) Duc, N. H.; Chauvy, F.; Herri, J.-M. $\mathrm{CO}_{2}$ capture by hydrate crystallization - A potential solution for gas emission of steelmaking industry. Energ. Convers. Manage. 2007, 48, $1313-1322$

(3) Arjmandi, M.; Chapoy, A.; Tohidi, B. Equilibrium Data of Hydrogen, Methane, Nitrogen, Carbon Dioxide, and Natural Gas in Semi-Clathrate Hydrates of Tetrabutyl Ammonium Bromide. J. Chem. Eng. Data 2007, 52, 2153-2158

(4) Oyama, H.; Shimada, W.; Ebinuma, T.; Kamata, Y.; Takeya, S.; Uchida, T.; Nagao, J.; Narita, H. Phase diagram, latent heat, and specific heat of TBAB semiclathrate hydrate crystals. Fluid Phase Equilib. 2005, 234, 131-135

(5) Lin, W.; Delahaye, A.; Fournaison, L. Phase equilibrium and dissociation enthalpy for semiclathrate hydrate of $\mathrm{CO}_{2}+$ TBAB. Fluid Phase Equilib. 2008, 264, 220-227

(6) Deschamps, J.; Dalmazzone, D. Dissociation enthalpies and phase equilibrium for TBAB semi-clathrate hydrates of $\mathrm{N}_{2}, \mathrm{CO}_{2}, \mathrm{~N}_{2}+\mathrm{CO}_{2}$ and $\mathrm{CH}_{4}+\mathrm{CO}_{2}$. J. Therm. Anal. Calorim. 2009, 98, 113-118

(7) Sabil, K. M.; Witkamp, G.-J.; Peters, C. J. Phase equilibria in ternary (carbon dioxide + tetrahydrofuran + water) system in hydrate-forming region: effects of carbon dioxide concentration and the occurrence of pseudo-retrograde hydrate phenomenon. J. Chem. Thermodyn. 2010, 42, 8-16

(8) Seo, Y.-T.; Kang, S.-P.; Lee, H. Experimental determination and thermodynamic modeling of methane and nitrogen hydrates in the presence of THF, propylene oxide, 1,4-dioxane and acetone. Fluid Phase Equilib. 2001, 189, 99-110 
(9) Delahaye, A.; Fournaison, L.; Marinhas, S.; Chatti, I.; Petitet, J. P.; Dalmazzone, D.; Fürst, W. Effect of THF on equilibrium pressure and dissociation enthalpy of $\mathrm{CO}_{2}$ hydrates applied to secondary refrigeration, Ind. eng. chem. res. 2006, 45, 391-397

(10) Kang, S. P.; Lee, H.; Lee, C. S.; Sung, W. M. Hydrate phase equilibria of the guest mixtures containing $\mathrm{CO}_{2}, \mathrm{~N}_{2}$ and tetrahydrofuran, Fluid Phase Equilib. 2001, 185, 101-109

(11) Linga, P.; Kumar, R.; Englezos, P. The clathrate hydrate process for post and precombustion capture of carbon dioxide, J.hazard. mater. 2007, 149, 625-629, 2007.

(12) Linga, P.; Kumar, R.; Lee, J. D.; Ripmeester, J.; Englezos, P. A new apparatus to enhance the rate of gas hydrate formation: Application to capture of carbon dioxide, Int. J. Greenh. Gas Control 2010, 4, 630-637.

(13) Kang, S.-P.; Lee, H. Recovery of $\mathrm{CO}_{2}$ from Flue Gas Using Gas Hydrate: Thermodynamic Verification through Phase Equilibrium Measurements. Environ. Sci. Technol. 2000, 34, 4397-4400

(14) Fan, S. S.; Liang, D.; Guo, K. Hydrate Equilibrium Conditions for Cyclopentane and a Quaternary Cyclopentane-Rich Mixture. J. Chem. Eng. Data 2001, 46, 930-932

(15) Zhang, J.; Lee, J.W. Equilibrium of Hydrogen + Cyclopentane and Carbon Dioxide + Cyclopentane Binary Hydrates. J. Chem. Eng. Data 2009, 54, 659-661

(16) Zhang, J.; Yedlapalli, P.; Lee, J. W. Thermodynamic analysis of hydrate-based precombustion capture of $\mathrm{CO}_{2}$. Chem. Eng. Sci. 2009, 64, 4732-4736.

(17) Zhang, J.; Lee, J.W. Enhanced Kinetics of $\mathrm{CO}_{2}$ Hydrate Formation under Static Conditions. Ind. Eng. Chem. Res. 2009, 48, 5934-5942.

(18) Mohammadi, A. H.; Richon, D. Phase equilibria of clathrate hydrates of methyl cyclopentane, methyl cyclohexane, cyclopentane or cyclohexane+carbon dioxide. Chem. Eng. Sci. 2009, 64, 5319-5322.

(19) Tohidi, B.; Danesh, A.; Todd, A.C.; Burgass, R. W.; Ostergaard, K. K. Equilibrium data and thermodynamic modelling of cyclopentane and neopentane hydrates. Fluid Phase Equilib. 1997, $138,241-250$.

(20) Du, J.; Liang, D.; Li, D.; Li, X. Experimental Determination of the Equilibrium Conditions of Binary Gas Hydrates of Cyclopentane plus Oxygen, Cyclopentane plus Nitrogen, and Cyclopentane plus Hydrogen. Ind. Eng. Chem. Res. 2010, 49, 11797-11800.

(21) Mohammadi, A. H.; Richon, D. Phase equilibria of binary clathrate hydrates of nitrogen + cyclopentane/cyclohexane/methyl cyclohexane and ethane + cyclopentane/cyclohexane/methyl cyclohexane. Chem. Eng. Sci. 2011, 66, 4936-4940

(22) Li, S.; Fan, S.; Wang, J.; Lang, X.; Wang, Y. Clathrate Hydrate Capture of CO2 from Simulated Flue Gas with Cyclopentane/Water Emulsion. Chinese J. Chem. Eng. 2010, 18, 202-206. 
(23) Herri, J.-M.; Bouchemoua, A.; Kwaterski, M.; Fezoua, A.; Ouabbas, Y.; Cameirao, A. Gas hydrate equilibria for $\mathrm{CO}_{2}-\mathrm{N}_{2}$ and $\mathrm{CO}_{2}-\mathrm{CH}_{4}$ gas mixtures - Experimental studies and thermodynamic modelling. Fluid Phase Equilib.2011, 301, 171-190.

(24) Thiam, A. L'étude des conditions thermodynamiques et cinétiques du procédé de captage du $\mathrm{CO}_{2}$ par formation d'hydrates de gaz Application au mélange $\mathrm{CO}_{2}-\mathrm{CH}_{4}, \mathrm{PhD}$ Thesis, Ecole Nationale Supérieure des Mines de St Etienne, 2008.

(25) Tohidi, B.; Burgass, R.W.; Danesh, A.; Ostergaard, K. K.; Todd, A. C.; Holder, G. D.; Bishnoi, P. R. Improving the accuracy of gas hydrate dissociation point measurements, in Gas hydrates: Challenges for the future. New York Acad Sciences 2000, 912, 924-931.

(26) Danesh, A.; Tohidi, B.; Burgass, R.; Todd, A. C. Hydrate Equilibrium Data of Methyl Cyclo-Pentane with Methane or Nitrogen. Chem. Eng. Res. Des. 1994, 72, 197-200.

(27) Mohr, P.J.; Taylor, B.N.; Newell, D.B. CODATA recommended values of the fundamental physical constants: 2010. J. Phys. Chem. Ref. Data 2012, 41.

(28) Holder, G. D.; Zetts, S. P.; Pradhan, N. Phase Behavior in Systems Containing Clathrate Hydrates: A Review, Rev. Chem. Eng. 1988, 5, 1-70.

(29) Galfré, A.; Fezoua, A.; Ouabbas, Y.; Cameirao, A.; Herri, J.M. Carbon dioxide hydrates crystallisation in emulsion. Proceedings of the 7th International Conference on Gas Hydrates 2011, Edimbourg, Royaume-Uni, 442.

(30) van der Waals, J.H; Platteeuw, J.C. Clathrate Solutions, Adv. Chem. Phys. 1959, 2, 1-57.

(31) Li, X.-S.; Xu, C.-G.; Chen, Z.-Y.; Cai, J. Synergic effect of cyclopentane and tetra-n-butyl ammonium bromide on hydrate-based carbon dioxide separation from fuel gas mixture by measurements of gas uptake and X-ray diffraction patterns. Int. J. Hydrogen Energ. 2012, 37, $720-727$

(32) Herslund, P. J.; Thomsen, K.; Abildskov, J.; Solms, N. V.; Galfré, A.; Brântuas, P.; Kwaterski, M.; Herri, J.M. Thermodynamic promotion of carbon dioxide clathrate hydrate formation - An experimental study. Int. J. Greenh. Gas Con. 2013, DOI: JGGC-D-12-00511R1

(33) Scharlin, P. Carbon dioxide in water and aqueous electrolyte solutions, Oxford University Press, 1996.

(34) Diamond, L. W.; Akinfiev, N. N. Solubility of $\mathrm{CO}_{2}$ in water from -1.5 to $100{ }^{\circ} \mathrm{C}$ and from 0.1 to $100 \mathrm{MPa}$ : evaluation of literature data and thermodynamic modelling. Fluid Phase Equilib. 2003, 208, 265-290.

(35) O'Connell J.P.; Haile, J.M. Thermodynamics: Fundamentals for Applications. Cambridge, New York, Melbourne, Madrid, Cape Town, Singapore, São Paolo: Cambridge University Press, 2005.

(36) Soave, G. Equilibrium constants from a modified Redlich-Kwong equation of state, Chem. Eng. Sci. 1972, 27, 1197-1203 
(37) Bonnefoy, O. Influence de cristaux d'hydrates de gaz ou de glace sur la perméabilité d'un milieu poreux. PhD Thesis, Ecole Nationale Supérieure des Mines de St Etienne, 2005.

(38) Vidal, J. Thermodynamics: Applications in Chemical Engineering and the Petroleum Industry. Editions Technip, 2003.

(39) Assael, M.J.; Trusler, J.P.M.; Tsolakis, T.F. Thermophysical Properties of Fluids. Imperial college Press: London U. K., 1996.

(40) Perry, R.H.; Green, D.W. Perry's Chemical Engineers' Handbook. McGraw-Hill, 2007. 


\section{AUTHOR INFORMATION}

\section{Corresponding Author}

Jean Michel Herri, Ecole Nationale Supérieure des Mines de St Etienne, 158 cours Fauriel, 42023 St Etienne, FRANCE. phone: +00334 77420292 Fax : +0033 477499694

Aurélie Galfré, Ecole Nationale Supérieure des Mines de St Etienne, 158 cours Fauriel, 42023 St Etienne, FRANCE. phone: +00334 77429760 Fax : +0033 477499694

\section{Authors emails}

Aurélie Galfré, galfre@emse.fr

Ana Cameirao, cameirao@emse.fr

Matthias Kwaterski, kwaterski@emse.fr

Pedro Brântuas, brantuas@emse.fr

Jean Michel Herri*, herri@emse.fr 
Table of Content Graphic

Figure 1. Schematic representation of the experimental setup.

Figure 2. Microscopic picture of the cyclopentane droplets constituting the $\mathrm{CP}$ in water emulsion (CP mass fraction of 0.0767).

Figure 3. CP droplets size distribution in a $\mathrm{CP}$ in water emulsion ( $\mathrm{CP}$ mass fraction of 0.0767).

Figure 4. Dissolving and crystallisation steps of the experimental procedure. Evolution of liquid temperature $\mathrm{T}$ and pressure $\mathrm{p}$ over time during the solubilisation step without crystallisation.

Figure 5. Dissolving and crystallisation steps of the experimental procedure. Evolution of liquid temperature $\mathrm{T}$ and pressure $\mathrm{p}$ over time when crystallisation occurs during the solubilisation step.

Figure 6. Dissolving and crystallisation steps of the experimental procedure. Evolution of the gas phase mole fraction of $\mathrm{CO}_{2}$ over time.

Figure 7. Dissociation steps of the experimental procedure.

Figure 8. Experimental data and correlations of Henry's constant of carbon dioxide in water and in cyclopentane as function of the inverse temperature $\mathrm{T}$. 
Figure 9. Equilibrium Mole fraction of $\mathrm{CO}_{2}$ in the hydrate phase as function of the corresponding mole fraction of $\mathrm{CO}_{2}$ in the gas for different temperatures $\mathrm{T}$ between $282.5 \mathrm{~K}$ to $287.5 \mathrm{~K}$, in presence of cyclopentane. Comparison to simulations obtained by means of the in-house software "GasHyDyn" for the corresponding system without cyclopentane.

Figure 10. p-T-equilibrium dissociation data for $\mathrm{CO}_{2}, \mathrm{~N}_{2}$ and $\mathrm{CO}_{2}+\mathrm{N}_{2}$ and systems with and without cyclopentane. Experimental data from literature and from this work, and comparison to simulations obtained with the in-house programme "GasHyDyn" for carbon dioxide gas hydrates.

Figure 11. Gas hydrate equilibrium pressure $\mathrm{p}$ as function of the corresponding mole fraction of $\mathrm{CO} 2$ in the gas phase in the temperature range $\mathrm{T}$ from $282.8 \mathrm{~K}$ to $287.5 \mathrm{~K}$. Experimental data and simulations from the in-house "GasHyDyn" software.

Figure 12. Gas storage capacity for $\mathrm{CO}_{2}+\mathrm{N}_{2}$ gas mixtures from $282.5 \mathrm{~K}$ to $287.5 \mathrm{~K}$ as function of the mole fraction of $\mathrm{CO}_{2}$ in the gas

Figure 1 (supporting information). Calibration curve for the gas chromatographic measurements on the $\mathrm{CO}_{2} / \mathrm{N}_{2}$ gas. 